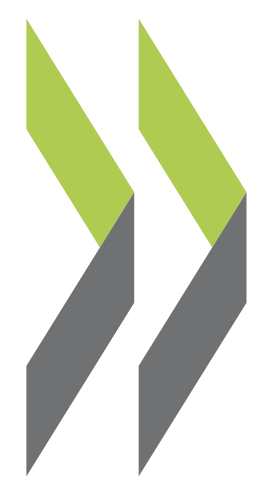

OECD Science, Technology and Industry Working Papers 2020/01

\title{
Measuring employment in global value chains
}

Peter Horvát,

Colin Webb,

\section{Norihiko Yamano}

https://dx.doi.org/10.1787/00f7d7db-en 


\section{OECD Science, Technology and Industry Working Papers}

OECD Working Papers should not be reported as representing the official views of the OECD or of its member countries. The opinions expressed and arguments employed are those of the authors. Working Papers describe preliminary results or research in progress by the author(s) and are published to stimulate discussion on a broad range of issues on which the OECD works. Comments on Working Papers are welcomed, and may be sent to OECD Directorate for Science, Technology and Innovation, OECD, 2 rue André-Pascal, 75775 Paris Cedex 16, France; e-mail: sti.contact@,oecd.org.

This document, as well as any data and map included herein, are without prejudice to the status of or sovereignty over any territory, to the delimitation of international frontiers and boundaries and to the name of any territory, city or area.

The statistical data for Israel are supplied by and under the responsibility of the relevant Israeli authorities. The use of such data by the OECD is without prejudice to the status of the Golan Heights, East Jerusalem and Israeli settlements in the West Bank under the terms of international law.

(C) OECD 2020

You can copy, download or print OECD content for your own use, and you can include excerpts from OECD publications, databases and multimedia products in your own documents, presentations, blogs, websites and teaching materials, provided that suitable acknowledgment of OECD as source and copyright owner is given. All requests for commercial use and translation rights should be submitted to rights@,oecd.org. 
MEASURING EMPLOYMENT IN GLOBAL VALUE CHAINS

Peter HORVÁT, Colin WEBB and Norihiko YAMANO

\begin{abstract}
Growing economic integration worldwide and the spread of global value chains (GVCs) increases the sensitivity of employment in one country or region to changes in demand in other countries or regions. However, traditional statistics do not reveal the full nature of global interdependencies - notably how consumption in one country may drive production and therefore, sustain employment in other economies or, how employment in an upstream domestic industry may be affected by exporting activities of other domestic industries.

This document describes the sources and methods used to produce the indicators in the Trade in employment (TiM) database. These indicators were developed, as a complement to Trade in Value Added (TiVA) indicators, to provide broad insights into the impact of GVCs on labour markets. The indicators are derived by combining the latest set of OECD Inter-Country Input-Output (ICIO) tables, covering the years 2005 to 2015, with appropriate employment by industry statistics.
\end{abstract}




\section{Table of contents}

OECD Science, Technology and Industry Working Papers................................................................. 2

MEASURING EMPLOYMENT IN GLOBAL VALUE CHAINS................................................... 3

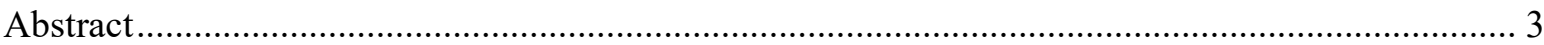

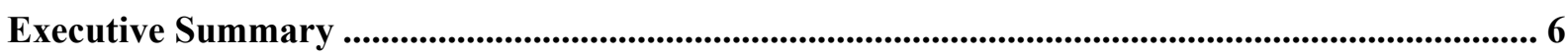

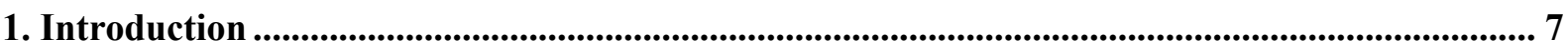

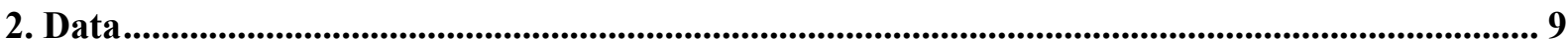

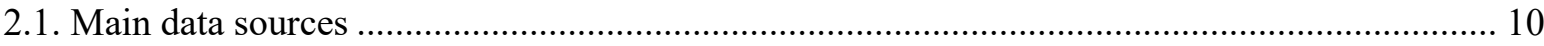

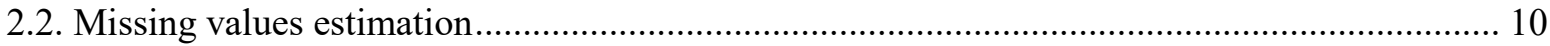

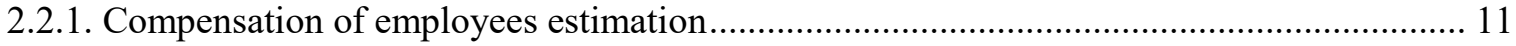

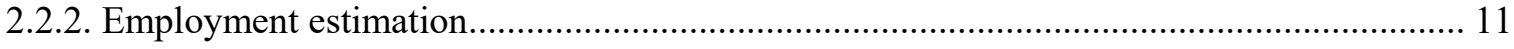

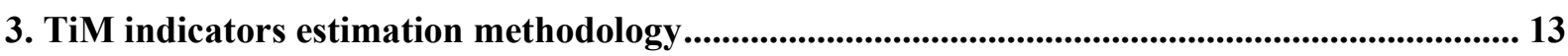

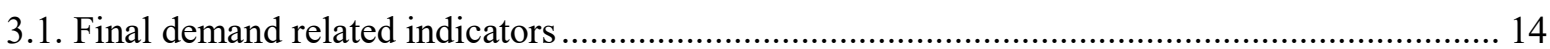

3.1.1. Domestic employment embodied in foreign final demand, thousand person ...................... 15

3.1.2. Share of domestic employment embodied in foreign final demand.................................... 16

3.1.3. Partner shares of domestic employment embodied in foreign final demand ....................... 17

3.1.4. Domestic compensation of employees content of foreign final demand, USD million ....... 18

3.1.5. Share of domestic compensation of employees embodied in foreign final demand ............ 19

3.1.6. Partner shares of domestic compensation of employees embodied in foreign final

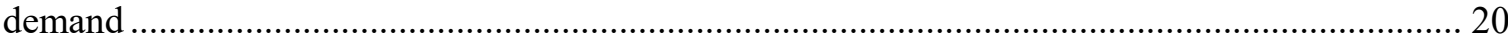

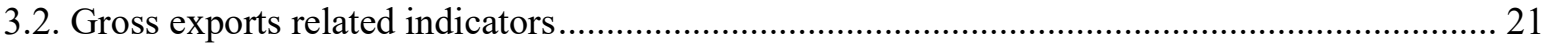

3.2.1. Domestic employment embodied in gross exports, thousand person.................................. 21

3.2.2. Direct, Indirect and Re-imported domestic employment embodied in gross exports,

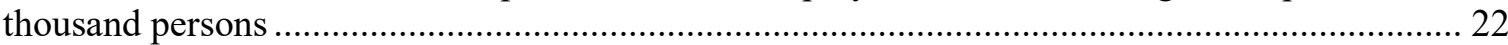

3.2.3. Share of domestic employment embodied in gross exports, percentage ............................. 23

3.2.4. Share of domestic employment embodied in exports of final and intermediate products,

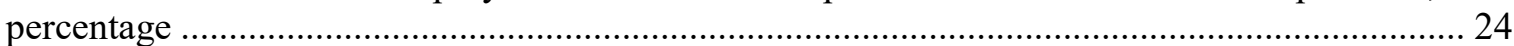

3.2.5. Domestic compensation of employees content of gross exports, USD million ................... 25

3.2.6. Direct, indirect and re-imported domestic compensation of employees content of gross

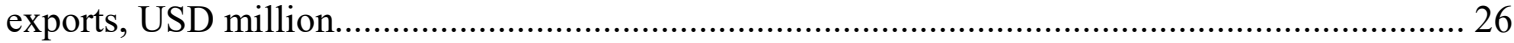

3.2.7. Domestic compensation of employees share of gross exports, percentage ......................... 27

3.2.8. Domestic compensation of employees sustained in exports of final and intermediate products as a share of total gross exports, percentage ............................................................... 28

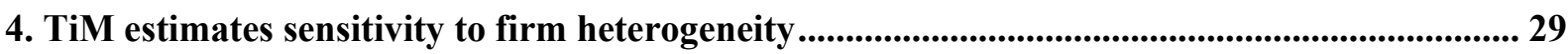

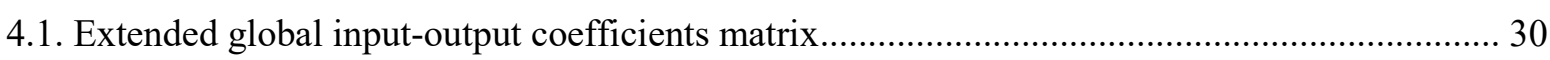

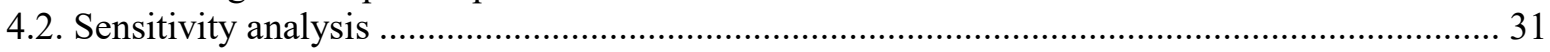

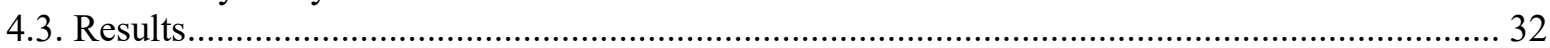

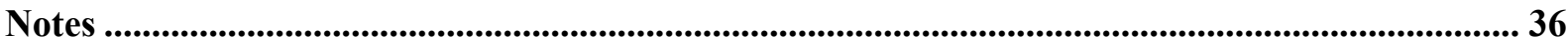

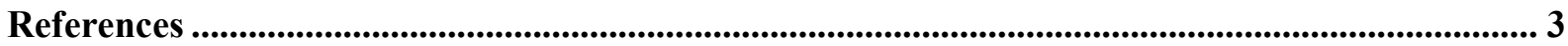

Appendix A-TiM Country list ..............................................................................................................5 5

Appendix B- TiM industry list ............................................................................................................ 7

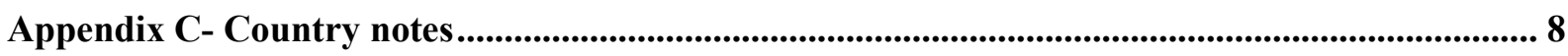




\section{Tables}

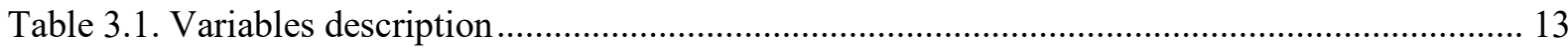

Table 4.1. Extended variables for heterogeneity simulation ............................................................. 30

Table 4.2. OECD countries: Summary of mean relative differences and its standard deviations from baseline scenario, by scenario

\section{Figures}

Figure 1.1. Employment sustained by foreign final demand, 2015

Figure 3.1. Domestic employment embodied in foreign final demand, G7, 2005 to $2015 \ldots \ldots \ldots \ldots \ldots \ldots \ldots$

Figure 3.2. Germany- employment sustained by foreign final demand by industry .......................... 16

Figure 3.3. China- Domestic manufacturing employment embodied in foreign final demand, by

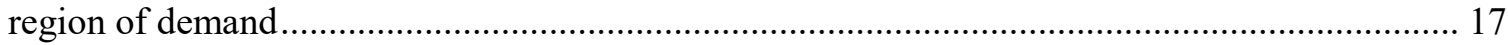

Figure 3.4. United States, Compensation of employees, origin of foreign final demand, by partner ... 18

Figure 3.5. OECD - Domestic compensation of employees in manufacturing embodied in foreign final demand

Figure 3.6. Domestic compensation of employees in manufacturing embodied in foreign final

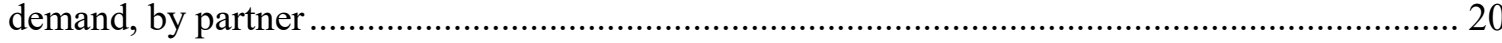

Figure 3.7. Domestic employment embodied in gross exports of manufactured goods, by partner ..... 21

Figure 3.8. United Kingdom - Domestic employment embodied in gross exports by industry, by origin of employment (direct domestic v. indirect domestic), 2015 ......................................... 22

Figure 3.9. Information and communication services, domestic employment embodied in gross exports, G7 countries.

Figure 3.10. G7 countries - Industry domestic employment embodied in gross exports, by type of

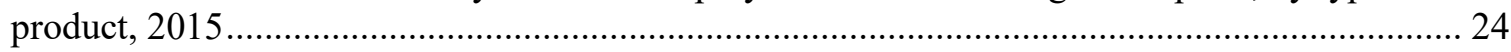

Figure 3.11. Domestic compensation of employees embodied in gross exports, G7 countries ........... 25

Figure 3.12. G7 countries -Domestic compensation of employees content of gross exports, total

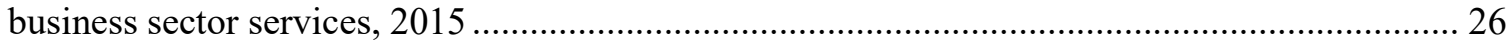

Figure 3.13. Domestic compensation of employees content of gross exports, total economy, G7 countries

Figure 3.14. Canada - Domestic compensation of employees' content of gross exports, by industry and type product, 2015

Figure 4.1. Two-country and two-industry example of Global intermediate consumption matrix split

Figure 4.2. OECD countries: Relative difference between baseline scenario of domestic employment embodied in gross exports and original EXGR_DEM estimates, 2015

Figure 4.3. OECD employment embodied in gross exports (weighted average), by scenario .............. 33

Figure 4.4. Relative difference between $-100 \%$ and baseline scenario for the OECD area, weighted

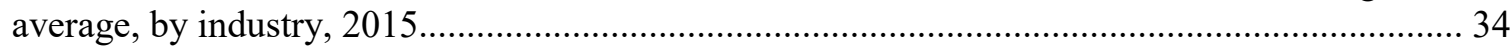

Figure 4.5. Confidence interval for manufacturing employment embodied in gross exports based on

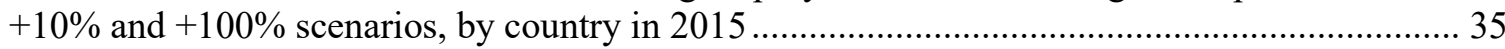




\section{Executive Summary}

Growing economic integration worldwide and the spread of global value chains (GVCs) increases the sensitivity of employment in one country or region to changes in demand in other countries or regions. However, traditional statistics do not reveal the full nature of global interdependencies - notably how consumption in one country may drive production and therefore, sustain employment in economies further up the value chain. The Trade in eMployment (TiM) indicators were developed, as complement to the TiVA indicators, to shed light on the origins of demand for a country's employment. Estimates of employment sustained by foreign final demand (or by exporting activities) can reveal the extent to which a country's workforce depends on its integration into the global economy.

In OECD member countries, on average, almost $30 \%$ of total employment is sustained by foreign final demand. For most economies, the major part of the foreign final demand originates from neighbouring countries. Even for countries with smaller dependency (in relative terms) on foreign demand such as the United States, with only around $9 \%$ of jobs sustained by foreign demand this still accounts, in absolute terms, for approximately 14 million jobs in total.

As well as indicators based on employment, the TiM database provides indicators concerning compensation of employees. The two major components of value added are compensation of employees and gross operating surplus of which profits, especially in foreign affiliates of multinational enterprises (MNEs), can be repatriated abroad. Thus, measures of domestic value added content of exports, or domestic value added embodied in foreign final demand, may overestimate the amount of value added that actually remains within the domestic economy. Wages and salaries, and associated supplements (social security, private pensions, health insurance etc.) tend to remain within the domestic economy. Thus indicators with a labour compensation perspective can represent lower bounds of the value added remaining in the domestic economy from the participation in global markets. In the OECD area, the labour share of value added embodied in foreign final demand was, on average, around $44 \%$ in 2015 although this varies significantly across countries.

An important assumption when constructing indicators of employment embodied in exports is that at the most detailed level of industry covered in the TiM database, labour productivity (expressed as output / employment), is the same for exporting firms and nonexporting firms. The ICIO tables do not distinguish between exporters and non-exporters except for China and Mexico, for which sufficient statistics exist to make such a split possible. However, empirical evidence from the international trade literature over last 20 years suggests that exporting firms tend to be more productive than non-exporting firms (in terms of labour productivity). This document outlines sensitivity tests for measures of employment embodied in gross exports, whereby a wide range of labour productivity differences between exporters and non-exporters are applied to provide some estimates of upper and lower bounds for the indicator. 


\section{Introduction}

A characteristic of economic globalisation is that labour markets in one country or region are sensitive to changes in demand in other countries or regions. However, official international trade or National Accounts statistics and even Supply and Use tables do not reveal the full nature of interdependencies - notably how consumers in one country may drive production and thus sustain jobs in economies further up the value chain.

OECD's Inter-Country Input-Output (ICIO) database was developed primarily to produce Trade in Value Added (TiVA) indicators (see http://oe.cd/tiva) such as foreign value added content of exports and domestic value added embodied in foreign final demand. However, the same database can be used to derive other metrics related to global value chains (GVCs) in particular, and, the subject of this report, indicators that provide insights into the origins of demand for a country's employment.

For example, estimates of domestic employment embodied in foreign final demand can capture the share of jobs used in production to satisfy foreign demand for final goods and services. Similarly, compensation of employees incurred in production can be disaggregated according to the origins of demand (both domestic and foreign). Estimates of employment, or compensation of employees, embodied in foreign final demand or gross exports can reveal the extent of a country's integration into the global economy.

The OECD's Trade in eMployment (TiM) database comprises indicators based on employment for 51 countries (determined by the availability of employment by industry statistics) and, indicators based on compensation of employees for the full set of 64 TiVA target economies (including all European Union, OECD and G20 member countries and most East and Southeast Asian economies) respectively. Indicators are presented for 36 unique industries and their aggregates covering the time period 2005 to 2015.

The importance of metrics that allow domestic employment to be decomposed into sources of demand is illustrated in Figure 1.1. In OECD member countries, on average almost 30\% of total employment is sustained by foreign final demand. For most OECD countries, the major part of the foreign final demand originates from neighbouring countries, which is especially true for the European Union (EU28) member countries. Even for countries with smaller dependency (in relative terms) on foreign demand such as the United States, with only around $9 \%$ of jobs sustained by foreign demand this still accounts, in absolute terms, for approximately 14 million jobs.

Over the period 2005 to 2015, the share of employment sustained by foreign final demand increased for almost all target countries as integration into global and regional value chains increased. However, this is not the case for all countries and there are various reasons for apparent falls. For some emerging economies (e.g. China) this may reflect increasing orientation of their economy towards the domestic market. Increased labour productivity in exporting industries may also have played a role. For countries such as Sweden, Finland and Canada, this may be due to the loss of the manufacturing jobs to service sectors. In Sweden, manufacturing accounted for $15.5 \%$ of total employment in 2005, but by 2015 this had fallen to $11.6 \%$. Similarly, Finland (17.1\% to $12.8 \%)$ and Canada (13.5\% to $9.2 \%)$ experienced notable falls in the manufacturing share of employment. 
Figure 1.1. Employment sustained by foreign final demand, 2015

As a percentage of total employment

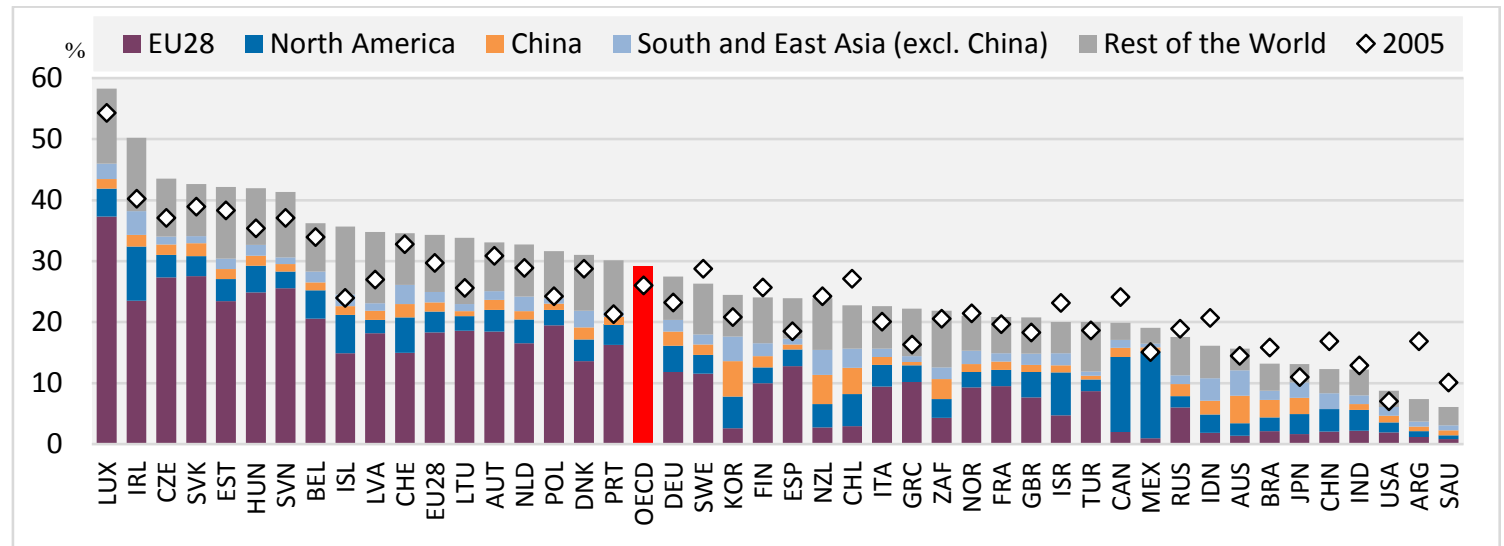

Note: The OECD and EU28 averages presented here include intra-regional flows. They represent unweighted averages of their member countries' shares.

Source: OECD Trade in Employment database, 2019, http://oe.cd/io-emp. 


\section{Data}

The TiM indicators are calculated using the 2018 edition of OECD's Inter-Country InputOutput (ICIO) database combined with recent estimates of employment and compensation of employees by industrial activity from official sources. To construct OECD's ICIO tables, national Supply and Use tables (SUTs) and Input-Output tables (IOTs) are transformed (or harmonised) to standard formats and classifications, combined with bilateral trade in goods and services statistics from international sources, and then balanced under constraints based on official (SNA) National Accounts by economic activity and National Accounts Main Aggregates time series. Prior to balancing, many data gaps are filled using a variety of estimation techniques. For more details, see http://oe.cd/icio where the underlying OECD ICIO tables are freely available for download.

As with TiVA indicators, the Trade in Employment indicators are sensitive to certain assumptions mainly due to data availability and limitations inherent in the construction of ICIO tables. Two main assumptions are that, for detailed industries, exporting firms have:

- The same labour productivity (expressed as output/employment) as firms producing goods and services for domestic markets. The only two exceptions to this assumption are Mexico and China, for which ICIO estimates are available separately for global manufacturers and firms serving the domestic market ("domestic" firms). ${ }^{1}$

- The same share of imported intermediates, in relation to output, as domestic firms.

However, international trade research over the last two decades, since the paper by Bernard and Jensen (1995), indicates that, in general, exporting firms have higher labour productivity. This is especially true for developing countries. Exporting firms, which are well integrated into global value chains, also tend to have a higher share of imported intermediates for a given output. Both differentials, in productivity and in intermediates use, imply that estimates of employment associated with exporting activities may be biased upwards.

On the other hand, due to data limitations, estimates of domestic employment embodied in foreign final demand or gross exports do not fully capture services associated with reexporting activities (e.g. transportation of untransformed imported goods across a country before being re-exported). Depending on the size of the re-exporting sector this may lead to a downward bias in the estimates.

In addition, employment embodied in final demand or gross exports may unduly capture employment in non-market activities. In particular, for some non-OECD countries, there is no differentiation between employment engaged in non-market agricultural ${ }^{2}$ activities and that used to produce intermediate agricultural goods.

Biases may also occur in cases where a "headquarter" firm in one country outsources manufacturing/assembly activities in another country while maintaining ownership of all inputs and outputs. High value added may be recorded for a headquarter firm with few employees, while low value added (manufacturing service fees) may be recorded for subcontractors abroad with many employees. The impact is highest when a headquarter firm dominates a particular industry within a (relatively small) country. 
Finally, note that the employment estimates are not full-time equivalent measures but rather headcounts and that the results relate to jobs sustained rather than created as the jobs may have previously existed to serve domestic consumers.

\subsection{Main data sources}

Domestic employment by industry statistics are drawn from various sources such as OECD's Annual National Accounts and Structural Analysis (STAN) databases, official national statistics and, in a very few cases, from research projects such as, for example, India KLEMS (Das et al., 2017). Employment is defined as persons engaged in production activity within the National Accounts boundary of the resident institutional unit (domestic concept) and includes both employees and self-employed. The preferred unit of measurement is persons although, if such statistics are unavailable then number of jobs by industry are used (see country notes in Appendix A).

If there are no estimates of employment by industry in official National Accounts statistics, then Labour Force Survey (LFS) statistics are exploited. National Accounts are preferred to LFS as a source for employment by industry since LFS are usually based on residential households and thus exclude non-resident workers while including resident workers commuting abroad (national concept).

For detailed industry information, the most common source is industry survey or Structural business statistics (SBS) coming from OECD, Eurostat, UNIDO or national sources.

Estimates of domestic compensation of employees by industry come from OECD's Supply and Use Tables, Annual National Accounts, STAN database or national sources. Compensation of employees, a major component of value added, include wages and salaries of employees paid by producers as well as supplements such as contributions to social security, private pensions, health insurance, life insurance and similar schemes.

In some cases when annual data series of Employment or Compensation of employees are published for fiscal years differing from calendar years, as for example Australia where fiscal year begins on the $1^{\text {st }}$ of July, lower frequency data (most commonly quarterly data) are used to transform series to calendar years.

\subsection{Missing values estimation}

In the case of missing detail for a target industry, the first step (same as in OECD's STAN database) is to use the hierarchical nature of the industry list:

- From the top level of the hierarchy, where data are available from the primary source (e.g. for ISIC Divisions 19 to 23, D19T23), the time-series correlations between the primary source and the secondary sources are calculated to choose the best secondary source (such as industrial survey data or Input-output tables). The selected secondary source is either used for filling in further detail (e.g. to estimate ISIC Divisions D19, D20T21, D22 and D23) or where necessary, extending the series backwards.

- To estimate missing information, the chosen secondary source data are adjusted for each year according to the relationship between the primary source and secondary source data at the lowest level for which they coincide (e.g. ISIC D19T23). The implicit assumption being that the relative distribution of the secondary source data within the subgroup is valid for the primary source (i.e. National Accounts). 
- Further adjustments to the estimates may be made to ensure that data at each level of the hierarchy of the industry list sums to the data at the superior level of the hierarchy.

\subsubsection{Compensation of employees estimation}

After exploiting all data sources, the compensation of employees' dataset still contained many gaps, mostly for non-OECD countries. In order to fill the gaps, and harmonise results with the latest TiVA estimates, a two-step procedure was applied:

- For all countries and industries, available data sources were used to obtain initial estimates of value added components, i.e. compensation of employees, gross operating surplus and other taxes on production, expressed as shares of industry value added. Remaining gaps were filled using either a simple 3-year moving average for series with at least one data point or otherwise, the share in value added of the closest available parent industry.

- This initial matrix was then balanced to match the row and column constraints for each year and country using a Generalised RAS procedure ${ }^{3}$. Industry value added shares of total value added from ICIO tables $(V A L U)$ were used as row constraints and total industry value added components share of total value added, from National Accounts, as column constraints.

This resulted in a full coefficient matrix of value added components. The Compensation of employees share on Value added (CEshVA) was later used to fill the gaps in the employment by industry database.

\subsubsection{Employment estimation}

If, after exploiting all employment data sources, there are still gaps in the employment by industry figures $(E M P N)$ for missing industry $i$ and missing year $t$, estimates are derived using the ratio of employment to compensation of employees $(E M C E)^{4}$ of the nearest higher industry aggregate $j$. Depending on the time availability of the industry data following formulas were used to fill missing industry detail:

- Target industry employment $i$ was missing for all years:

$$
E M P N_{i, t}=V A L U_{i, t} * C E \operatorname{shV} A_{i, t} * E M C E_{j, t}
$$

- In cases where the target industry employment estimates were absent for earlier years, extrapolation was carried out based on the growth rates of the nearest higher industry aggregate of the employment to compensation of employees ratio:

$$
E M P N_{i, t}=V A L U_{i, t} * C E \operatorname{shV} A_{c, i, t} * \frac{E M C E_{j, t}}{E M C E_{j, t+1}} * E M C E_{i, t+1}
$$

- Similarly, extrapolation was used for cases where the target industry employment estimates were absent for recent years:

$$
E M P N_{i, t}=V A L U_{i, t} * C E \operatorname{shV} A_{i, t} * \frac{E M C E_{j, t}}{E M C E_{j, t-1}} * E M C E_{j, t-1}
$$


The last step is to adjust estimates to match parent industries values within the hierarchy ${ }^{5}$. 


\section{TiM indicators estimation methodology}

The TiM indicators are derived through an input-output accounting framework, therefore, the mathematical notation used in this section builds on input-output theory as well. Table 3.1 summarises, for $k$ countries and $n$ industries, the matrices drawn from the OECD ICIO tables and employment statistics (see Chapter 2.2) used to generate employment related GVC indicators. For the 2018 version of ICIO, $\mathrm{k}=69$, representing the 64 TiVA target countries (see appendix), two additional entries for both Mexico and China to account for the separation of "global manufacturers" and "domestic serving firms" and, "the rest of the world"; $n=36$ unique target industries. For more detail on the split of global manufacturers and domestic serving firms, see Chapter 4.1

Table 3.1. Variables description

\begin{tabular}{|c|c|c|}
\hline Variable & Dimension & Description \\
\hline $\mathbf{X}$ & $1 \times\left(k^{*} n\right)$ & Gross output vector by country and industry \\
\hline LABR & $1 \times\left(k^{*} n\right)$ & Compensation of employees vector by country and industry \\
\hline EMPN & $1 \times\left(k^{*} n\right)$ & Employment vector by country and industry \\
\hline $\mathbf{e}^{e}$ & $1 \times\left(k^{*} n\right)$ & $\begin{array}{l}\text { Employment coefficient vector by country and industry, calculated as } \\
\mathbf{e}^{e}=\frac{\text { EMPN }}{\mathbf{X}}\end{array}$ \\
\hline $\mathbf{e}^{l}$ & $1 \times\left(k^{*} n\right)$ & $\begin{array}{l}\text { Compensation of employees coefficient vector by country and } \\
\text { industry, calculated as } \mathbf{e}^{l}=\frac{\text { LABR }}{\mathbf{X}}\end{array}$ \\
\hline A & $\left(k^{*} n\right) \times\left(k^{*} n\right)$ & Global Input-output coefficients matrix, calculated as $A_{i, j}=\frac{Z_{i, j}}{X_{j}}$ \\
\hline$A_{c}$ & $n \times n$ & Local Input-output coefficients matrix for country $c$ \\
\hline B & $\left(k^{*} n\right) \times\left(k^{*} n\right)$ & Global Leontief inverse matrix: $\mathbf{B}=(\mathbf{I}-\mathbf{A})^{-\mathbf{1}}$ \\
\hline $\mathbf{B}_{c}$ & $\mathrm{n} \times \mathrm{n}$ & Local Leontief inverse matrix $\mathbf{B}_{c}=\left(\mathbf{I}-\mathbf{A}_{c}\right)^{-\mathbf{1}}$ \\
\hline FD & $\left(k^{*} n\right) \times k$ & $\begin{array}{l}\text { Global final demand matrix showing the demand of country } p \text { (in } \\
\text { column) for goods and services from industry } i \text { in country } c \text { (rows) }\end{array}$ \\
\hline GT & $\left(k^{*} n\right) \times k$ & $\begin{array}{l}\text { Global bilateral gross trade matrix by exporting country and industry } \\
\text { to importing country for total goods and services } \\
\text { GT=GT_INT+GT_FNL }\end{array}$ \\
\hline GT_INT & $\left(k^{*} n\right) \times k$ & $\begin{array}{l}\text { Global bilateral gross trade matrix by exporting country and industry } \\
\text { to importing country for intermediate goods }\end{array}$ \\
\hline GT_FNL & $\left(k^{*} n\right) \times k$ & $\begin{array}{l}\text { Global bilateral gross trade matrix by exporting country and industry } \\
\text { to importing country for final goods }\end{array}$ \\
\hline
\end{tabular}

Source: OECD Inter-Country Input-Output (ICIO) Database, 2018, http://oe.cd/icio. 
Regional aggregates $\left(r=\left\{c_{1}, c_{2}, \ldots,\left|c_{r}\right|\right\}\right)$ are generated by aggregating member countries after completion of calculations for all countries. For region aggregates, TiM indicators exclude intra-regional trade or origins of demand (e.g. for EU28, exports to non-EU28 or demand from non-EU28 only). Regional aggregates for exports and final demand related indicators, in monetary terms or persons, are calculated as follows:

$$
\begin{aligned}
& \text { Indicator }_{c, i, r_{a}}=\left\{\begin{array}{l}
\text { country } c \in r_{a}: \sum_{p \in\left\{r_{a}-c\right\}} \text { Indicator }_{c, i, p} \\
\text { country } c \notin r_{a}: \sum_{p \in r_{a}} \text { Indicator }_{c, i, p}
\end{array}\right. \\
& \text { Indicator }_{r_{a}, i, p}=\left\{\begin{array}{l}
\text { partner country } p \in r_{a}: \\
\text { partner country } p \notin r_{a}: \\
\text { partner region } p=r_{b} \neq r_{a}:
\end{array} \quad \sum_{c \in\left\{r_{b}-\left(r_{a} \cap r_{b}\right)\right\}} \text { Indicator }_{c, i, p}\right.
\end{aligned}
$$

\subsection{Final demand related indicators}

Estimates of employment embodied in final demand are calculated in a similar manner to that of the TIVA indicator "Domestic value added embodied in foreign final demand". Rather than pre-multiplying the matrices with value added to output ratios as for TiVA indicators, to calculate employment embodied in final demand, the matrices are pre-multiplied by an employment coefficient. The employment coefficient represents the number of persons engaged per unit of industry output. Similar calculations are undertaken for compensation of employees where the coefficient consists of the shares of compensation of employees in industry output. Final demand includes household and government final consumption, Non-Profit Institutions Serving Households (NPISH), gross fixed capital formation (GFCF i.e. investment by firms), changes in inventories and direct purchases by non-residents. 


\subsubsection{Domestic employment embodied in foreign final demand, thousand person}

Domestic employment embodied in foreign final demand (FFD_DEM $\mathrm{F}_{c, i, p}$ ) captures the number of persons engaged by industry $i$ in country / region $c$, to satisfy final demand for goods and services in country/region $p$. This measure reflects the fluctuating origins of demand for goods and services produced domestically, i.e. an increase in industry employment to meet foreign final demand does not necessarily translate into an increase in total industry employment if at the same time employment in production to meet domestic demand decreases. FFD_DEM is calculated as:

$$
\text { FFD_DEM }=\widehat{\mathbf{e}^{e}} \times \mathbf{B} \times \text { FD, }
$$

where FFD_DEM is a matrix of size $\left(k^{*} n \times k\right)$ with rows corresponding to source industry $i$ and source country $c$ employment sustained by final demand for goods from country $p$ in columns. Matrix $\widehat{\mathbf{e}^{e}}(k * n \times k * n)$ represents the diagonalised employment coefficient vector. This indicator is available only for partner countries/regions $p \neq c$ or in other words when $p=c=>\sum_{i}$ FFD_DEM $_{c, i, p=c}=0$.

Figure 3.1 shows the evolution of domestic employment used in production to meet foreign final demand for G7 countries, 2005 to 2015. While in relative terms, United States employment is the least dependant among OECD countries on demand originating from abroad, with less than $10 \%$ of employment sustained by foreign final demand, in absolute terms, it tops all other OECD countries for all target years. Employment sustained by foreign final demand grew in all G7 countries after a fall in 2009 although in Canada it had not reached pre-crises levels by 2015 .

Figure 3.1. Domestic employment embodied in foreign final demand, G7, 2005 to 2015

Total industry, millions

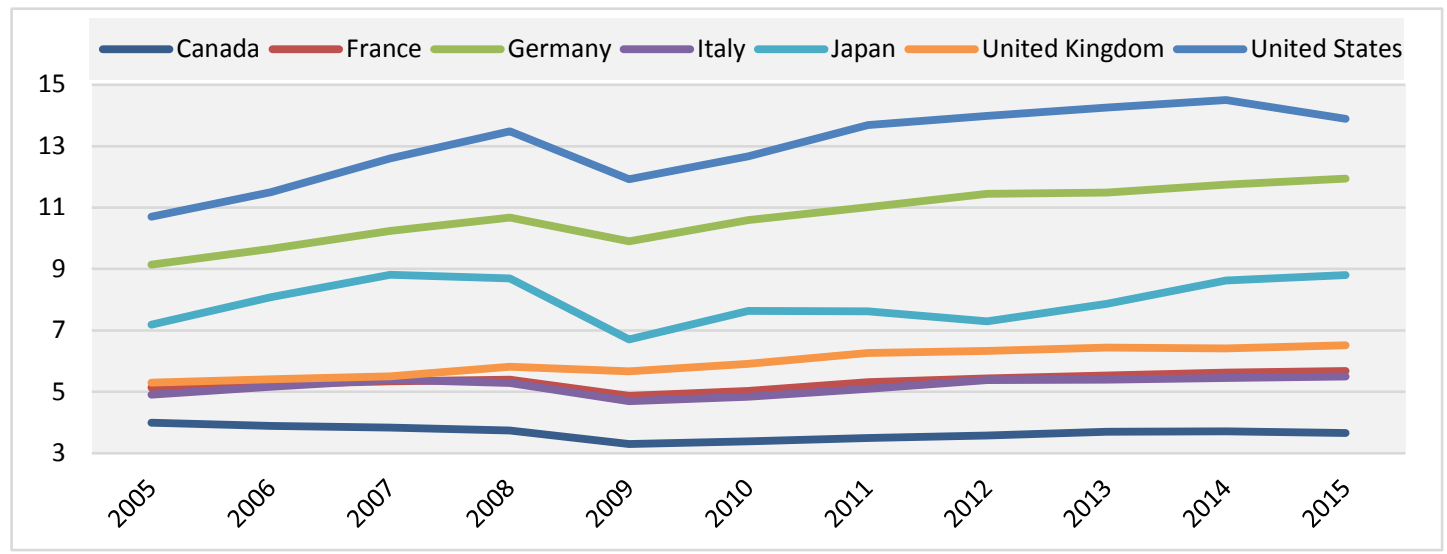

Source: OECD Trade in Employment database, 2019, http://oe.cd/io-emp. 


\subsubsection{Share of domestic employment embodied in foreign final demand}

Share of domestic employment embodied in foreign final demand (EMPN_FFDDEM $c_{c, i}$ ), for country / region $c$ and industry $i$ is defined as domestic employment embodied in foreign final demand (FFD_DEM $\mathrm{F}_{c, i, p}$ ) as a percentage of total industry $i$ employment in country/ region $c,\left(\mathrm{EMPN}_{c, i}\right)$.

$$
\text { EMPN_FFDDEM }_{c, i}=\frac{\sum_{\boldsymbol{p}} \text { FFD_DEM }_{c, i, p}}{\mathrm{EMPN}_{c, i}} \times 100
$$

The share of employment meeting foreign final demand varies considerably across industries. For example, Figure 3.2 illustrates the relatively high and growing dependency of German manufacturing employment on foreign final demand, between 2005 and 2015, compared to service sectors.

Figure 3.2. Germany- employment sustained by foreign final demand by industry

As a percentage of industry total employment

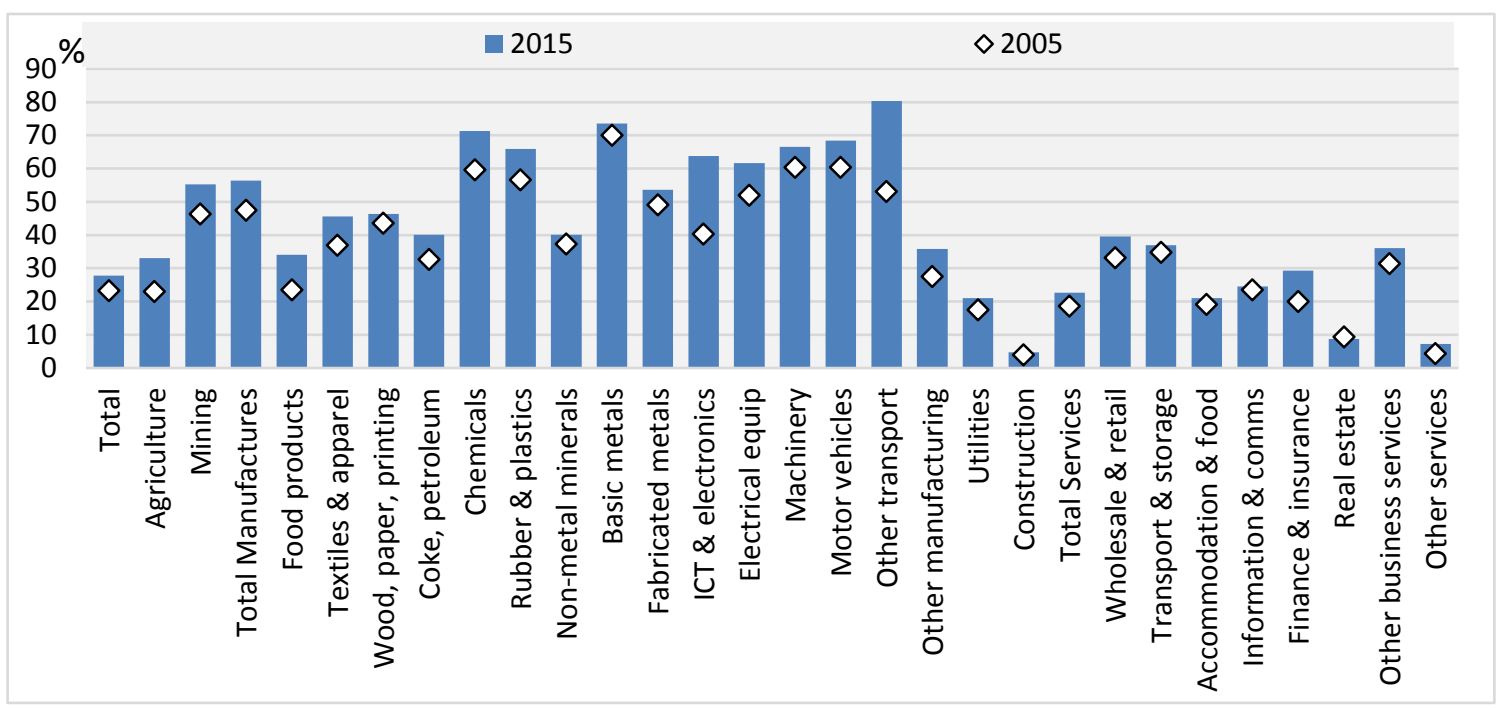

Source: OECD Trade in Employment database, 2019, http://oe.cd/io-emp. 


\subsubsection{Partner shares of domestic employment embodied in foreign final demand}

Partner shares of domestic employment embodied in foreign final demand $\left(\right.$ FFD_DEMPSH $\left.H_{c, i, p}\right)$ shows, for country/ region $c$ and industry $i$, the percentage shares of domestic employment embodied in foreign final demand accounted for by each foreign demand country/ region $p$.

$$
\text { FFD_DEMPSH }_{c, i, p}=\frac{\text { FFD_DEM }_{c, i, p}}{\sum_{p} \text { FFD_DEM }_{c, i, p}} \times 100
$$

Partner shares indicators, such as FFD_DEMPSH, can reveal the trends and importance of other countries', or regions', final demand on a country's employment. Figure 3.3 shows the distribution of regional demand for employment in China's manufacturing sector and the development over time. Between 2005 and 2015, dependency on developed economies decreased. North America was still the main foreign source of demand for Chinese manufacturing employment in 2015 but, along with the European Union (EU28) and Japan and Korea, its importance fell significantly.

Figure 3.3. China- Domestic manufacturing employment embodied in foreign final demand, by region of demand

As a percentage of total domestic manufacturing employment embodied in foreign final demand

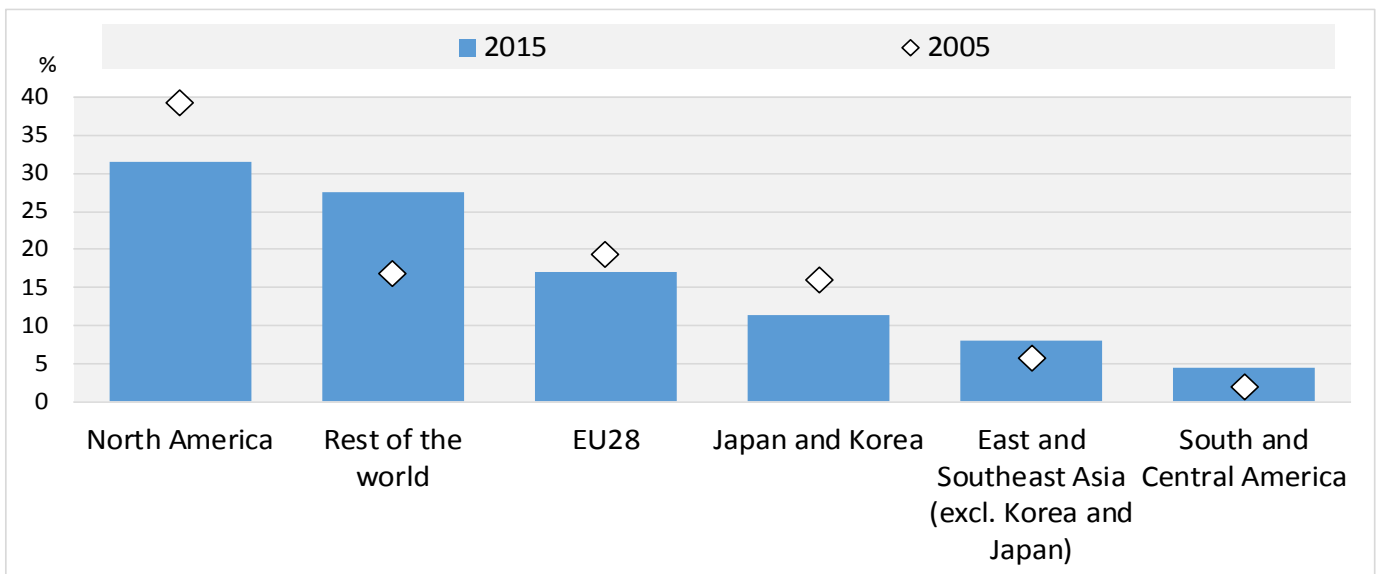

Note: North America consists of Canada, United States and Mexico; South and Central America includes Argentina, Brazil, Chile, Colombia, Costa Rica and Peru.

Source: OECD Trade in Employment database, 2019, http://oe.cd/io-emp. 


\subsubsection{Domestic compensation of employees content of foreign final demand, USD million}

Domestic compensation of employees content of foreign final demand (FFD_DCE $E_{c, i, p}$ ) shows estimates of compensation of employees incurred in production by industry $i$ in country / region $c$ to satisfy final demand for goods and services in country / region $\mathrm{p}$.

$$
\text { FFD_DCE }=\widehat{\mathbf{e}}^{l} \times \mathbf{B} \times \text { FD, }
$$

where FFD_DCE is a matrix of size $\left(k^{*} n \times k\right)$ with rows corresponding to source industry $i$ and source country $c$ compensation of employees sustained by final demand for goods from country $p$ in columns. Matrix $\widehat{\mathbf{e}^{l}}(k * n \times k * n)$ represents the diagonalised Compensation of employees coefficient. This indicator is available only for partner countries/regions $p \neq c$ or in other words when $\sum_{i}$ FFD_DCE $_{c, i, p=c}=0$.

Indicators related to compensation of employees in the TiM database are presented and can be used in a similar fashion as the employment- or value added-based indicators. Users are encouraged to compare and link these with TiVA indicators but comparisons with the employment-based indicators should be made with caution. Total employment includes both employees and self-employed and while dividing compensation of employees by total employment to get a proxy of wages may be tempting, the results could be biased ${ }^{6}$. Measures of domestic value added (DVA) embodied in foreign demand and DVA content of exports, in the TiVA database, include income that may be repatriated by multinational enterprises (encapsulated in the "gross operating surplus" component of value added). Equivalent measures based on compensation of employees may give an indication of the minimum amount of domestic value added that remains in the economy due to exporting activities.

Figure 3.4. United States, Compensation of employees, origin of foreign final demand, by partner

Total economy, USD billions

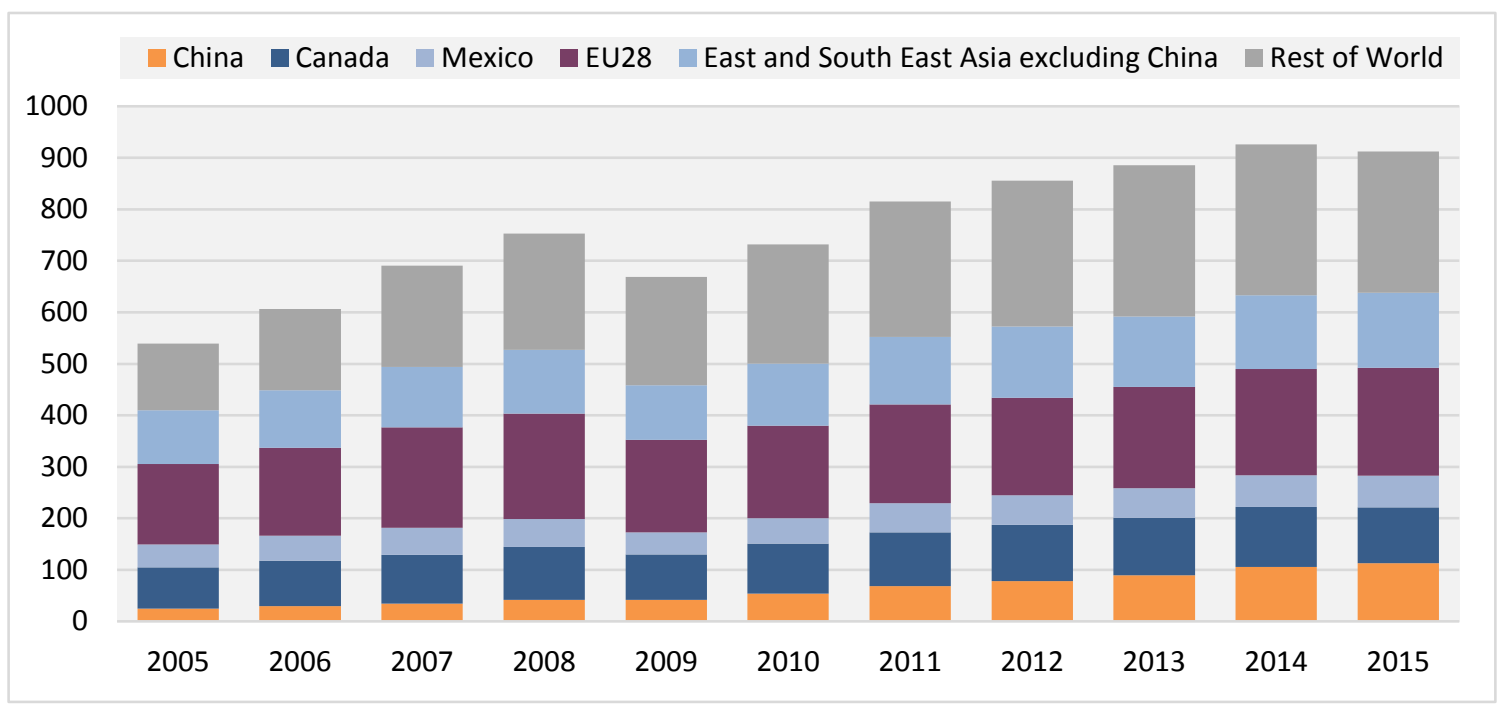

Source: OECD Trade in Employment database, 2019, http://oe.cd/io-emp. 


\subsubsection{Share of domestic compensation of employees embodied in foreign final demand}

Share of domestic compensation of employees embodied in foreign final demand $\left(\mathrm{LABR} F F D D C E_{c, i}\right)$ for country/ region $c$ and industry $i$ is defined as domestic compensation of employees embodied in foreign final demand (FFD_DCE $\mathrm{F}_{c, i, p}$ ) as a percentage of total industry $i$ compensation of employees in country/ region $c,\left(\operatorname{LABR}_{c, i}\right)$.

$$
\text { LABR_FFDDCE }_{c, i}=\frac{\sum_{p} \mathrm{FFD}_{-} \mathrm{DCE}_{c, i, p}}{\mathrm{LABR}_{c, i}} \times 100
$$

In many countries, the share of compensation of employees sustained by foreign final demand increased over the period 2005 to 2015. In 2015, the OECD member countries weighted average was $41.7 \%$ up from $35.7 \%$ in 2005 . The variation, even among G7 member countries, is quite high - in 2015, from about $22 \%$ in the United States to about $59 \%$ in Germany.

Figure 3.5. OECD - Domestic compensation of employees in manufacturing embodied in foreign final demand

As a percentage of total manufacturing compensation of employees

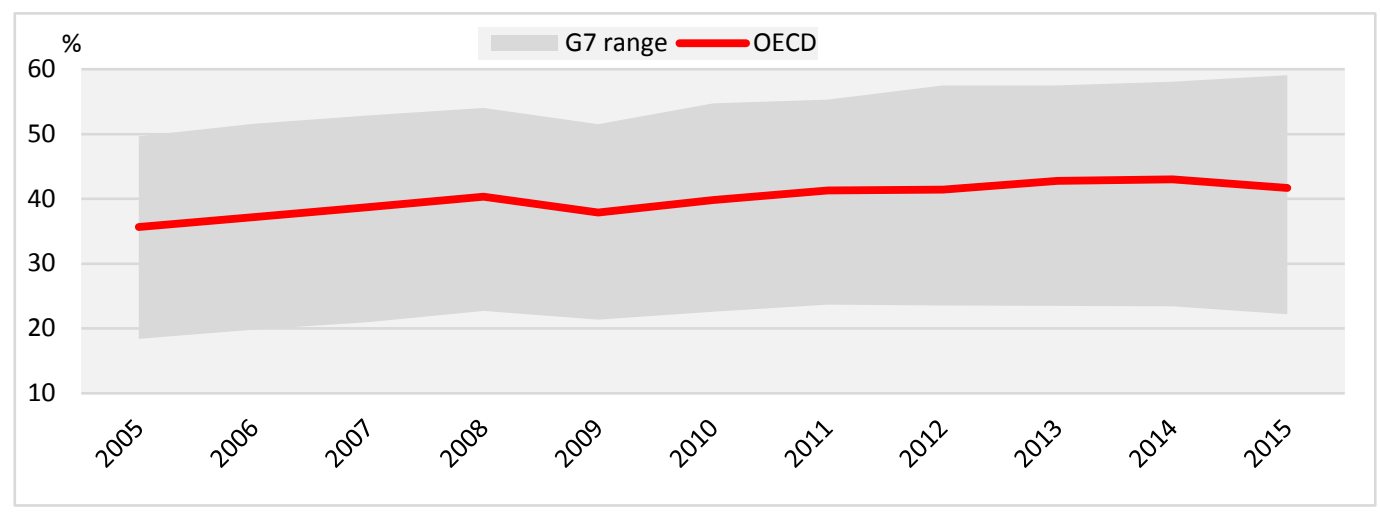

Note: OECD is calculated as weighted average of OECD member countries and including intra OECD flows (unweighted OECD average is significantly higher, around 56\% in 2015).

Source: OECD Trade in Employment database, 2019, http://oe.cd/io-emp. 


\subsubsection{Partner shares of domestic compensation of employees embodied in foreign final demand}

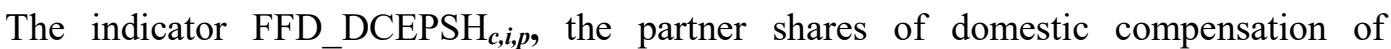
employees embodied in foreign final demand, shows, for country/ region $c$ and industry $i$, the percentage shares of domestic compensation of employees embodied in foreign final demand accounted for by each foreign demand country/ region $p$.

$$
\text { FFD_DCEPSH }_{c, i, p}=\frac{\text { FFD_DCE }_{c, i, p}}{\sum_{p} \text { FFD_DCE }_{c, i, p}} \times 100
$$

Figure 3.6. Domestic compensation of employees in manufacturing embodied in foreign final demand, by partner

Selected bilateral flows, percentage

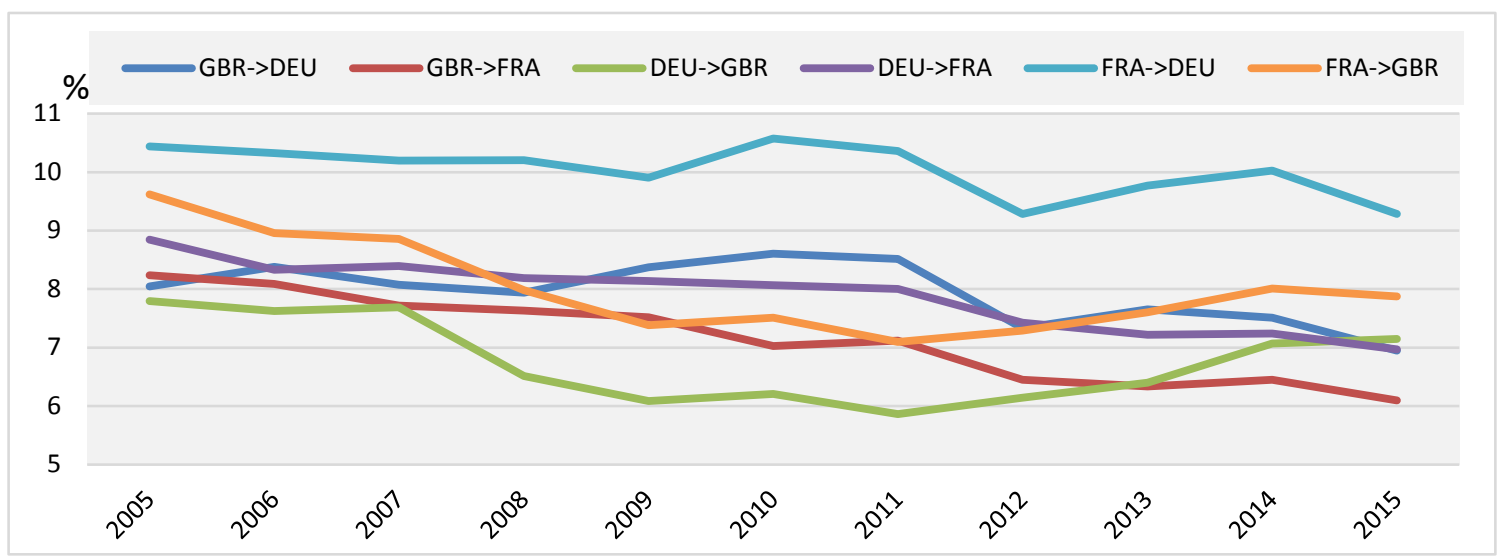

Source: OECD Trade in Employment database, 2019, http://oe.cd/io-emp. 


\subsection{Gross exports related indicators}

The employment and compensation of employees indicators embodied in gross exports are derived in a similar manner to the TiVA indicator "Domestic value added embodied in gross exports". Depending on the type of exporting goods, TiM contains three different indicators for total exports and split to final and intermediate goods and services.

Domestic employment embodied in gross exports includes both the employment in the exporting industry and, employment in other (upstream) domestic industries embodied in intermediate inputs used by the exporting industry. Therefore, it is possible that employment embodied in an industry's gross exports can exceed employment in that industry. For a better understanding of the impact of the exporting industry on domestic employment, this indicator is decomposed into three components capturing direct, indirect and reimported effects.

\subsubsection{Domestic employment embodied in gross exports, thousand person}

Domestic employment embodied in gross exports, EXGR_DEM ${ }_{c, i, p}$, represents for industry $i$ in country/ region $c$, the domestic employment embodied in exports to partner country / region $p$. It covers employment that has been used anywhere in the domestic economy (i.e. not just by the exporting industry $i$ but also by other, upstream, domestic industries $\neq i$ ).

$$
\text { EXGR_DEM }_{c, i, p}=\mathrm{e}_{\mathbf{c}}^{\mathrm{e}} \times \mathbf{B}_{\mathbf{c}, \mathbf{c}} \times \widehat{\mathbf{G T}_{\mathbf{c}, \mathbf{p}}} \times \alpha_{i}
$$

where $\mathbf{e}_{\mathbf{c}}^{\mathbf{e}}$ is a $1 \times n$ vector, with domestic employment over production coefficients for each country $c$ and industry $i$. $\mathbf{B}_{\mathbf{c , c}}$ corresponds to a $n \times n$ diagonal block matrix of global Leontief inverse matrix $\mathbf{B}$. $\widehat{\mathbf{G T}_{\mathbf{c}, \mathbf{p}}}$ represents a $n \times n$ matrix of diagonalised gross exports vector from country $c$ to partner country $p$ for all industries. $\boldsymbol{\alpha}_{\boldsymbol{i}}$ is a $n \times 1$ vector with value equal to one for industry $i$ and zero to all other entries.

Figure 3.7. Domestic employment embodied in gross exports of manufactured goods, by partner

Selected bilateral flows, thousand persons

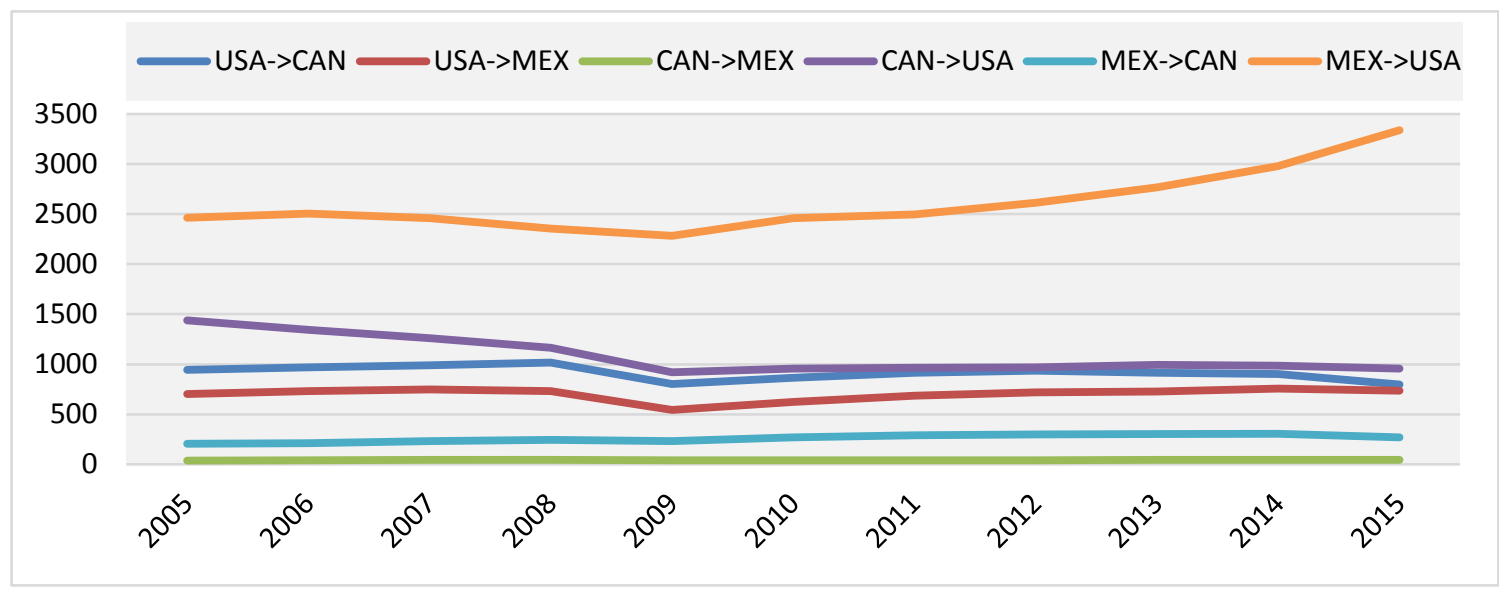

Source: OECD Trade in Employment database, 2019, http://oe.cd/io-emp. 


\subsubsection{Direct, Indirect and Re-imported domestic employment embodied in gross exports, thousand persons}

Direct domestic employment embodied in gross exports $\left(\operatorname{EXGR}_{-} \mathrm{EMD}_{c, i}\right)$, measures employment in industry $i$ used in the production of goods and services exported by industry $i$ in country $c$.

$$
\mathrm{EXGR}_{-} \mathrm{EMD}_{c, i}=\mathrm{e}_{\mathbf{c}}^{\mathrm{e}} \times \mathbf{d i a g B}_{\boldsymbol{c}} \times \widehat{\mathbf{G T}_{\mathbf{c}, \mathbf{p}}} \times \alpha_{i},
$$

where $\operatorname{diagB}_{\boldsymbol{c}}$ consists of the diagonal elements of the local Leontief inverse matrix $\mathbf{B}_{\boldsymbol{c}}$, i.e. with zeros in the off-diagonal cells, displaying the direct requirements.

Indirect domestic employment embodied in gross exports, EXGR_EMI $I_{c, i}$, measures employment in other, upstream, domestic industries (different from industry $i$ ) in country $c$ that is embodied in the exports of industry $i$.

$$
\text { EXGR_EMI }_{c, i}=\mathrm{e}_{\mathbf{c}}^{\mathrm{e}} \times \mathbf{o f f d i a g \mathbf { B } _ { \boldsymbol { c } }} \times \widehat{\mathbf{G T}_{\mathbf{c}, \mathbf{p}}} \times \alpha_{i},
$$

where offdiagB $\mathbf{B}_{\boldsymbol{c}}$ represents the local Leontief inverse matrix $\mathbf{B}_{\boldsymbol{c}}$ with zeros of all diagonal elements i.e. showing the indirect requirements.

Re-imported domestic employment embodied in gross exports, EXGR_EMR ${ }_{c, i}$, measures the domestic employment, by any industry in country $c$, used to produce exports of intermediate goods or services subsequently embodied in imports used in the production of exports by industry $i$ in country $c$.

$$
\begin{aligned}
& \text { EXGR_EMR }_{c, i}=\sum_{p}\left(\text { EXGR_DEM }_{c, i, p}\right)-\text { EXGR_EMD }_{c, i}- \\
& \text { EXGR_EMI }_{c, i}
\end{aligned}
$$

Figure 3.8. United Kingdom - Domestic employment embodied in gross exports by industry, by origin of employment (direct domestic v. indirect domestic), 2015

As a percentage of exporting industry employmen

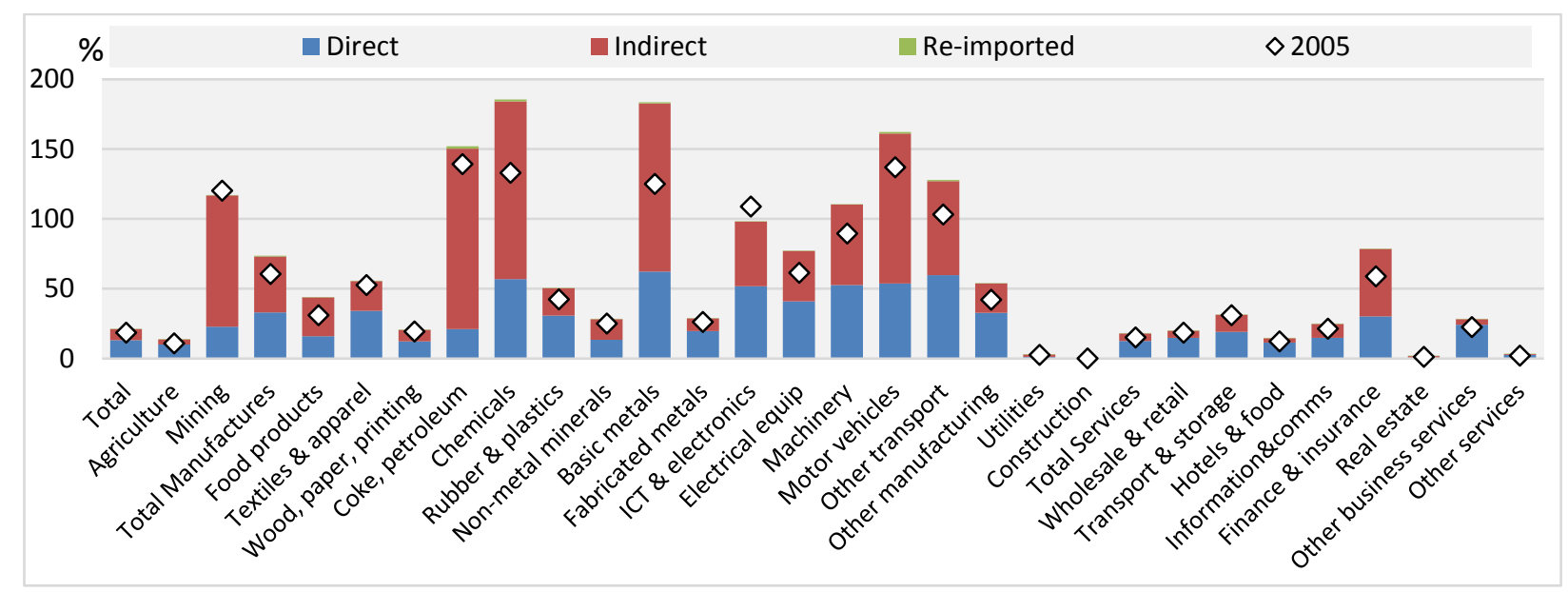

Source: OECD Trade in Employment database, 2019 


\subsubsection{Share of domestic employment embodied in gross exports, percentage}

Share of domestic employment embodied in gross exports (EMPN_EXGRDEM ${ }_{c, i}$ ), for domestic industry $i$ in country $c$, is defined as domestic employment embodied in gross exports $\left(E X G R \_D E M_{c, i, p}\right)$ as a percentage of total employment $\left(\mathrm{EMPN}_{c, i}\right)$.

$$
\text { EMPN_EXGRDEM }_{c, i}=\frac{\sum_{p} \text { EXGR_DEM }_{c, i, p}}{\mathrm{EMPN}_{c, i}} \times 100
$$

Figure 3.9. Information and communication services, domestic employment embodied in gross exports, G7 countries

As a percentage of total employment in Information and communication services

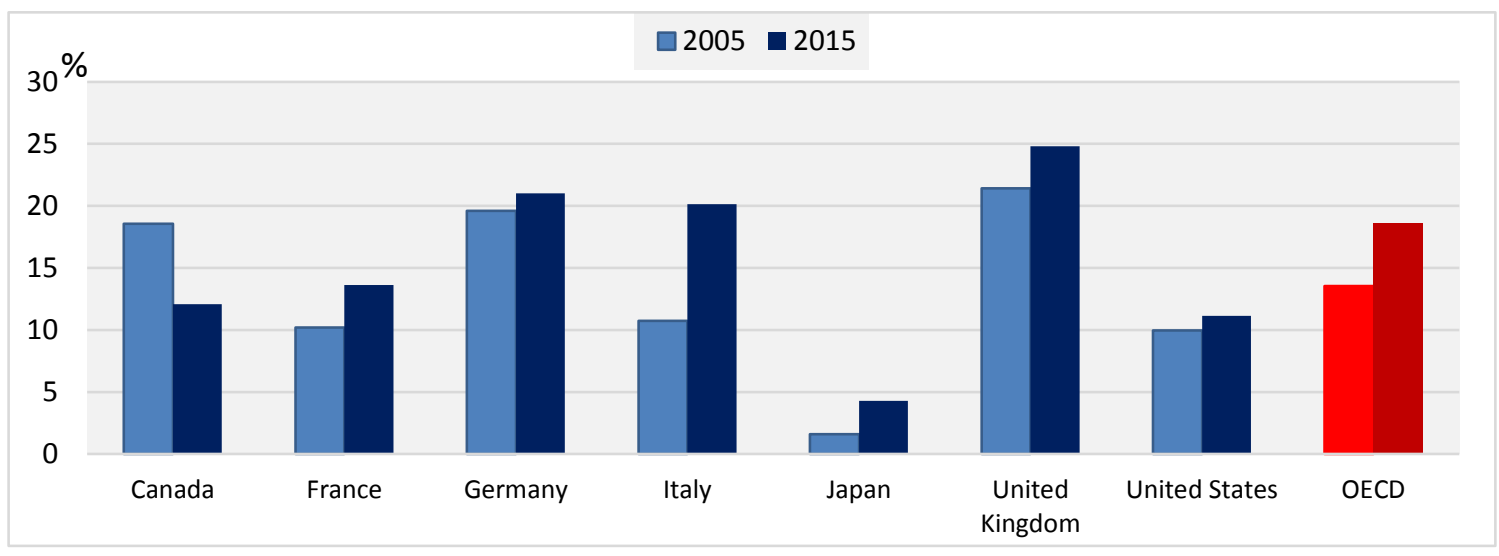

Source: OECD Trade in Employment database, 2019, http://oe.cd/io-emp. 


\subsubsection{Share of domestic employment embodied in exports of final and intermediate products, percentage}

EMPN_EXFNLDEM $M_{c, i}$ is defined as the share of domestic employment embodied in exports of final products, by industry $i$ in country $c$, as a percentage of total domestic employment $\left(\mathrm{EMPN}_{c, i}\right)$.

$$
\text { EMPN_EXFNLDEM }_{c, i}=\frac{\sum_{p}\left(\mathrm{e}_{\mathbf{c}}^{\mathrm{e}} \times \mathbf{B}_{\mathbf{c}, \mathbf{c}} \times \mathbf{G T}_{-} \widehat{\mathbf{F N L}}_{\mathbf{c}, \mathbf{p}} \times \alpha_{i}\right)}{\mathrm{EMPN}_{c, i}} \times 100,
$$

where $\mathbf{G T}_{\mathbf{F N L}} \widehat{\mathbf{F N}}_{\mathbf{p}}$ is a $n \times n$ matrix of diagonalised gross exports of final products vector.

EMPN_EXINTDEM ${ }_{c, i}$ is defined as the share of domestic employment embodied in exports of intermediate products, by industry $i$ in country $c$, as a percentage of total domestic employment $\left(\mathrm{EMPN}_{c, i}\right)$.

$$
\text { EMPN_EXINTDEM }_{c, i}=\frac{\sum_{p}\left(\mathrm{e}_{\mathbf{c}}^{\mathrm{e}} \times \mathbf{B}_{\mathbf{c}, \mathbf{c}} \times \mathbf{G T} \mathbf{T I N T}_{\mathbf{c}, \mathbf{p}} \times \alpha_{i}\right)}{\operatorname{EMPN}_{c, i}} \times 100,
$$

where $\mathbf{G T}_{\mathbf{I N T}}^{\mathbf{c}, \mathbf{p}}$ is a $n \times n$ matrix of diagonalised gross exports of intermediate products vector.

Figure 3.10. G7 countries - Industry domestic employment embodied in gross exports, by type of product, 2015

As a percentage of industry employment

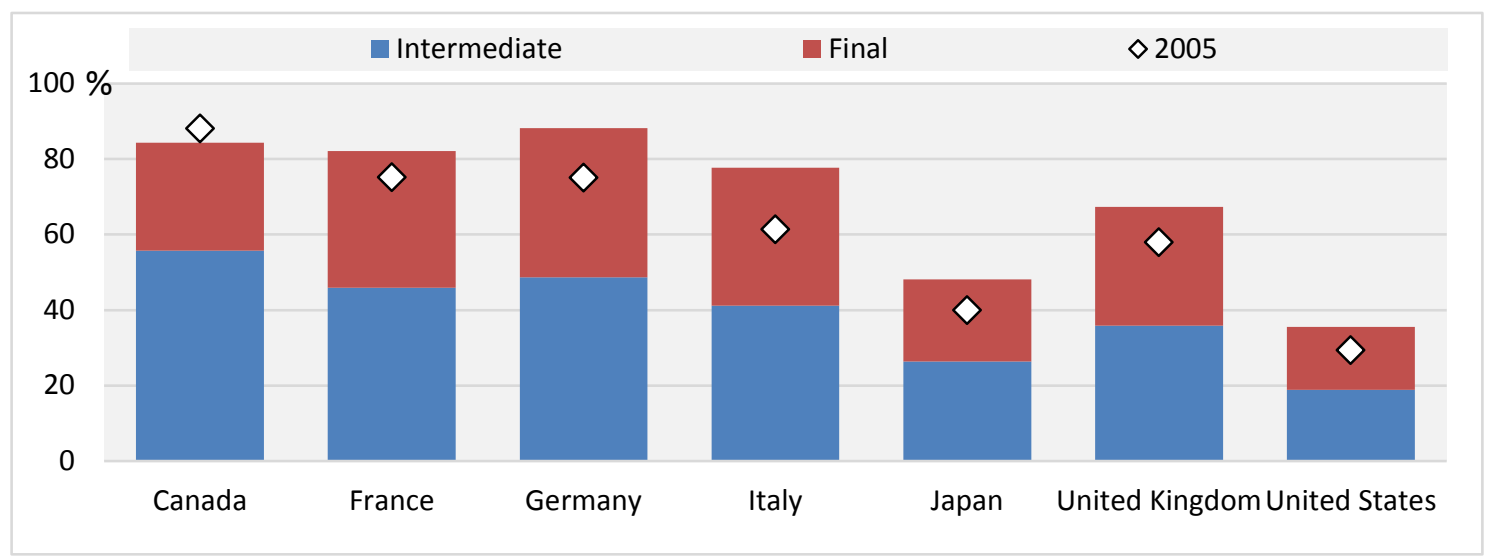

Note: Industry includes mining, manufacturing and utilities (ISIC Rev.4 Divisions 05 to 39)

Source: OECD Trade in Employment database, 2019, http://oe.cd/io-emp. 


\subsubsection{Domestic compensation of employees content of gross exports, USD million}

Domestic compensation of employees content of exports (EXGR_DCE $\mathrm{E}_{c, i, p}$ ), by industry $i$ in country/region $c$ to partner country/region $p$, represents the compensation of employees content of exported value added that has been generated anywhere in the domestic economy (i.e. not just by the exporting industry).

$$
\text { EXGR_DCE }_{c, i, p}=\mathrm{e}_{\mathbf{c}}^{l} \times \mathbf{B}_{\mathbf{c}, \mathbf{c}} \times \widehat{\mathbf{G T}_{\mathbf{c}, \mathbf{p}}} \times \alpha_{i},
$$

where $\mathrm{e}_{\mathrm{c}}^{l}$ is a $1 \times n$ vector, with domestic compensation of employees share on production for each country $c$ and industry $i$.

Figure 3.11. Domestic compensation of employees embodied in gross exports, G7 countries

$$
\text { Total economy, USD billions }
$$

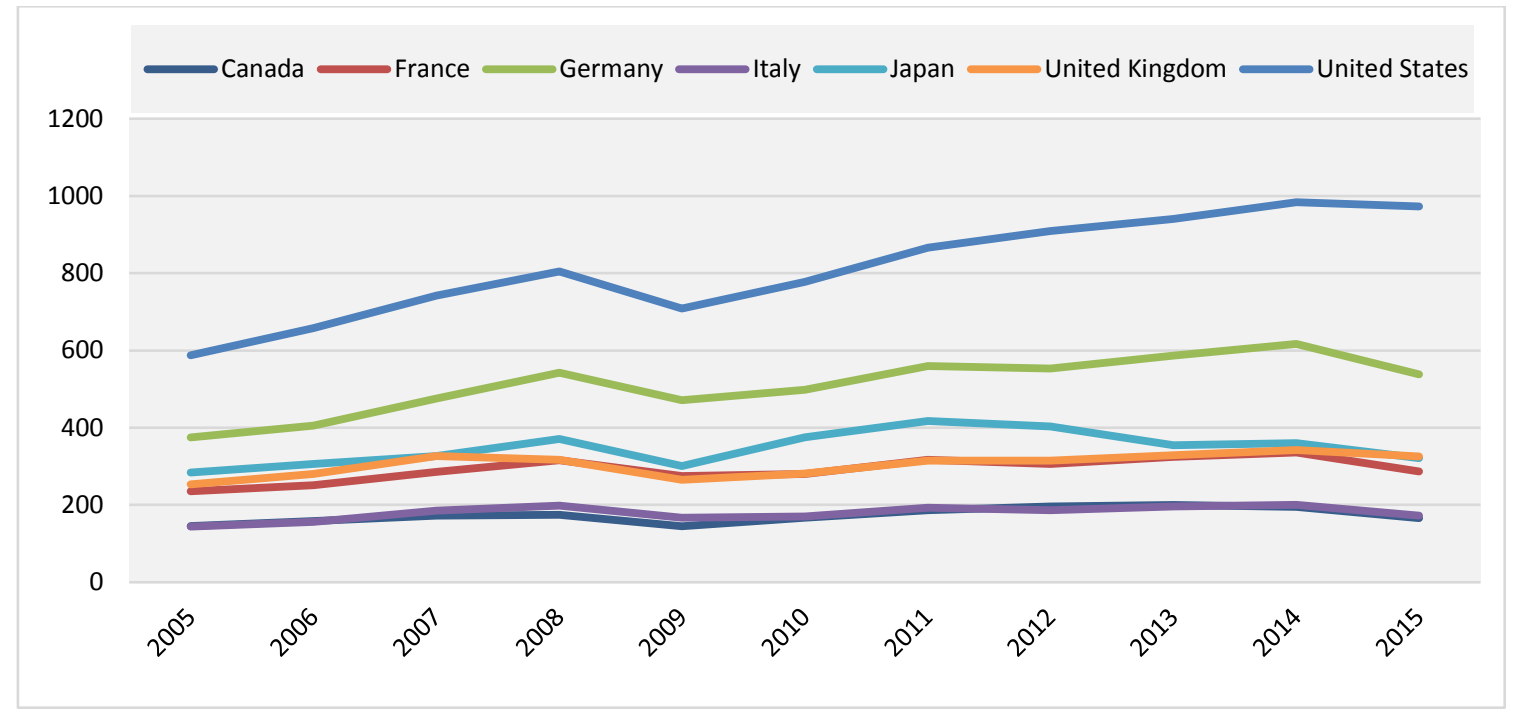

Source: OECD Trade in Employment database, 2019, http://oe.cd/io-emp. 


\subsubsection{Direct, indirect and re-imported domestic compensation of employees content of gross exports, USD million}

Direct domestic compensation of employees' content of gross exports (EXGR_CED ${ }_{c, i}$ ), measures the domestic compensation of employees paid directly by industry $i$ in country $c$ to produce the goods or services exported by industry $i$ in country $c$.

$$
\text { EXGR_CED }_{c, i}=\mathrm{e}_{\mathbf{c}}^{l} \times \operatorname{diagB}_{\boldsymbol{c}} \times \widehat{\mathbf{G T}_{\mathbf{c}, \mathbf{p}}} \times \alpha_{i}
$$

Indirect domestic compensation of employees' content of gross exports (EXGR_CEI I,$i_{i}$, corresponds to the compensation of employees paid by other, upstream, domestic industries (different from industry $i$ ) in country $c$ that are embodied in the exports of industry $i$ in country $c$.

$$
\text { EXGR_CEI } I_{c, i}=\mathrm{e}_{\mathrm{c}}^{l} \times \mathbf{o f f d i a g \mathbf { B } _ { \boldsymbol { c } }} \times \widehat{\mathbf{G T}_{\mathbf{c}, \mathbf{p}}} \times \alpha_{i}
$$

Re-imported domestic compensation of employees content' of gross exports (EXGR_CER ${ }_{c, i}$ ), measures the domestic compensation of employees, paid by any industry in country $c$, to produce exports of intermediate goods or services subsequently embodied in imports used in the production of exports by industry $i$ in country $c$.

$$
\begin{aligned}
& \text { EXGR_CER }_{c, i}=\sum_{p}\left(\mathrm{EXGR}_{-} D C E_{c, i, p}\right)-\mathrm{EXGR}_{-} \mathrm{CED}_{c, i}- \\
& \text { EXGR_CEI }_{c, i}
\end{aligned}
$$

Figure 3.12. G7 countries -Domestic compensation of employees content of gross exports, total business sector services, 2015

As a percentage of total business sector services' compensation of employees

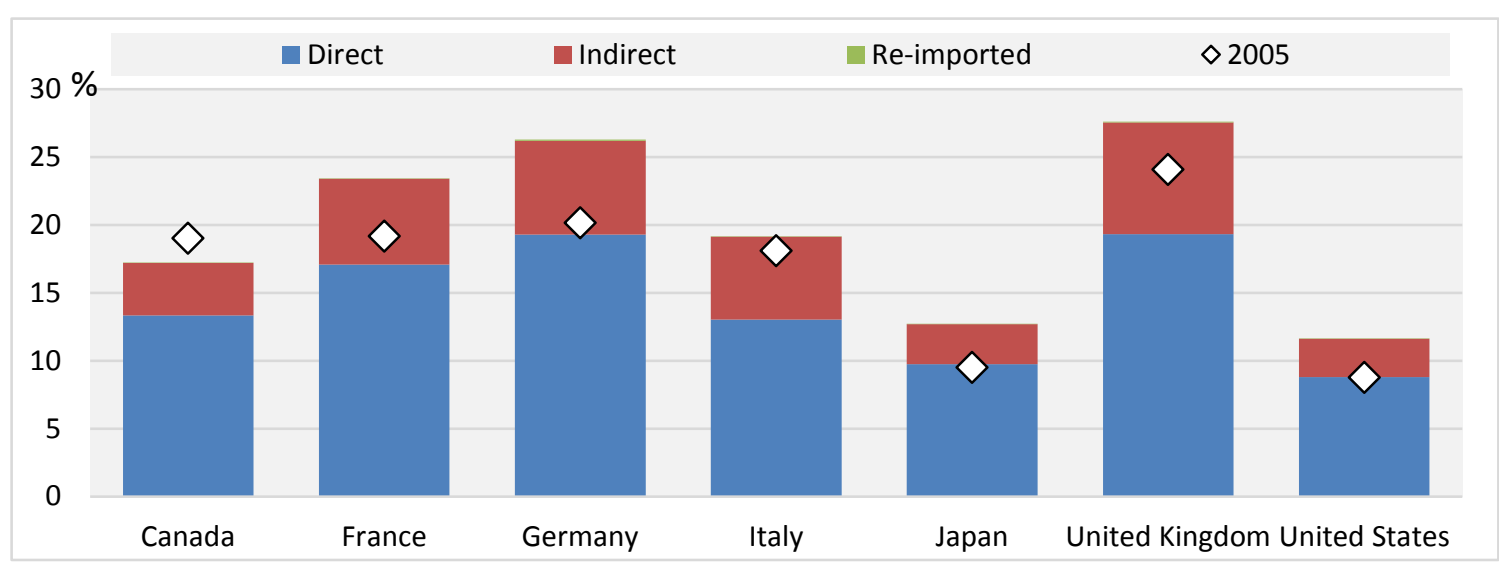

Source: OECD Trade in Employment database, 2019, http://oe.cd/io-emp. 


\subsubsection{Domestic compensation of employees share of gross exports, percentage}

Domestic compensation of employees share of gross exports, for domestic industry $i$ in country $c\left(\mathrm{EXGR}_{-} \mathrm{DCESH} \mathrm{C}_{c, i}\right)$, is defined as domestic compensation of employees in gross exports $\left(\mathrm{EXGR}_{-} \mathrm{DCE} \mathrm{E}_{c, i, p}\right)$ as a percentage of total gross exports $\left(\mathrm{GT}_{c, i, p}\right)$. It is an "intensity measure" and reflects how much compensation of employees, generated anywhere in the domestic economy, is embodied per unit of total gross exports by industry $i$.

$$
\text { EXGR_DCESH }_{c, i}=\frac{\sum_{p} \text { EXGR_DCE }_{c, i, p}}{\sum_{p} \mathrm{GT}_{c, i . p}} \times 100
$$

Figure 3.13. Domestic compensation of employees content of gross exports, total economy, G7 countries

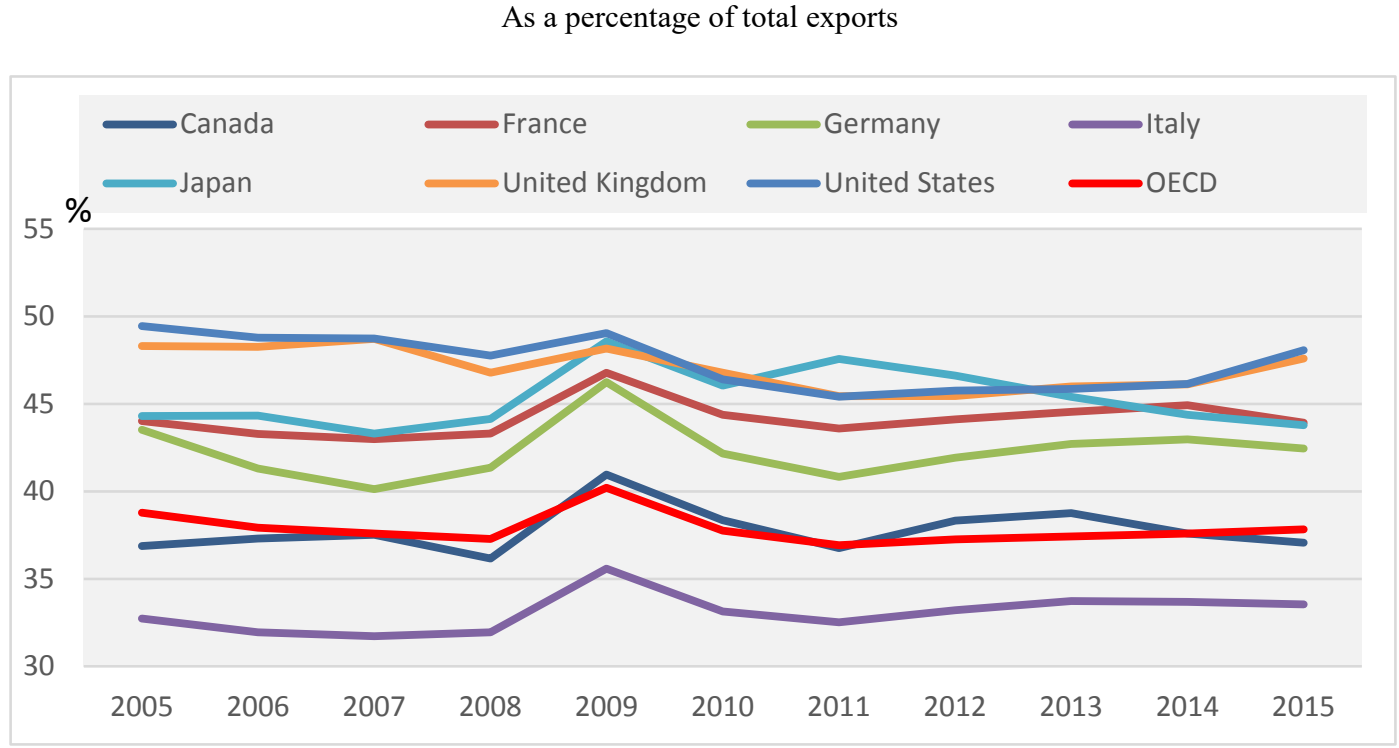

Source: OECD Trade in Employment database, 2019, http://oe.cd/io-emp. 


\subsubsection{Domestic compensation of employees sustained in exports of final and} intermediate products as a share of total gross exports, percentage

EXGR_FNLDCESH $\mathrm{H}_{c, i}$ is defined as domestic compensation of employees in exports of final products as a share of total gross exports $\left(\mathrm{GT}_{c, i, p}\right)$, by industry $i$ in country $c$.

$$
\text { EXGR_FNLDCESH }_{c, i}=\frac{\sum_{p}\left(\mathrm{e}_{\mathrm{c}}^{l} \times \mathbf{B}_{\mathbf{c}, \mathbf{c}} \times \mathrm{GT}_{-} \mathrm{FNL}_{\mathrm{c}, \mathrm{i}, \mathrm{p}}\right)}{\sum_{p} \mathrm{GT}_{c, i, p}} \times 100
$$

EXGR_INTDCESH $\mathrm{E}_{c, i}$ is defined as domestic compensation of employees in exports of intermediate products as a share of total gross exports $\left(\mathrm{GT}_{c, i, p}\right)$, by industry $i$ in country $c$

$$
\text { EXGR_INTDCESH }_{\boldsymbol{c}, \boldsymbol{i}}=\frac{\sum_{p}\left(\mathrm{e}_{\mathrm{c}}^{l} \times \mathbf{B}_{\mathbf{c}, \mathbf{c}} \times \mathrm{GT}_{-} \mathrm{INT}_{\mathrm{c}, \mathrm{i}, \mathrm{p}}\right)}{\sum_{p} \mathrm{GT}_{c, i, p}} \times 100
$$

Figure 3.14. Canada - Domestic compensation of employees' content of gross exports, by industry and type product, 2015

As a share of industry compensation of employees, percentage

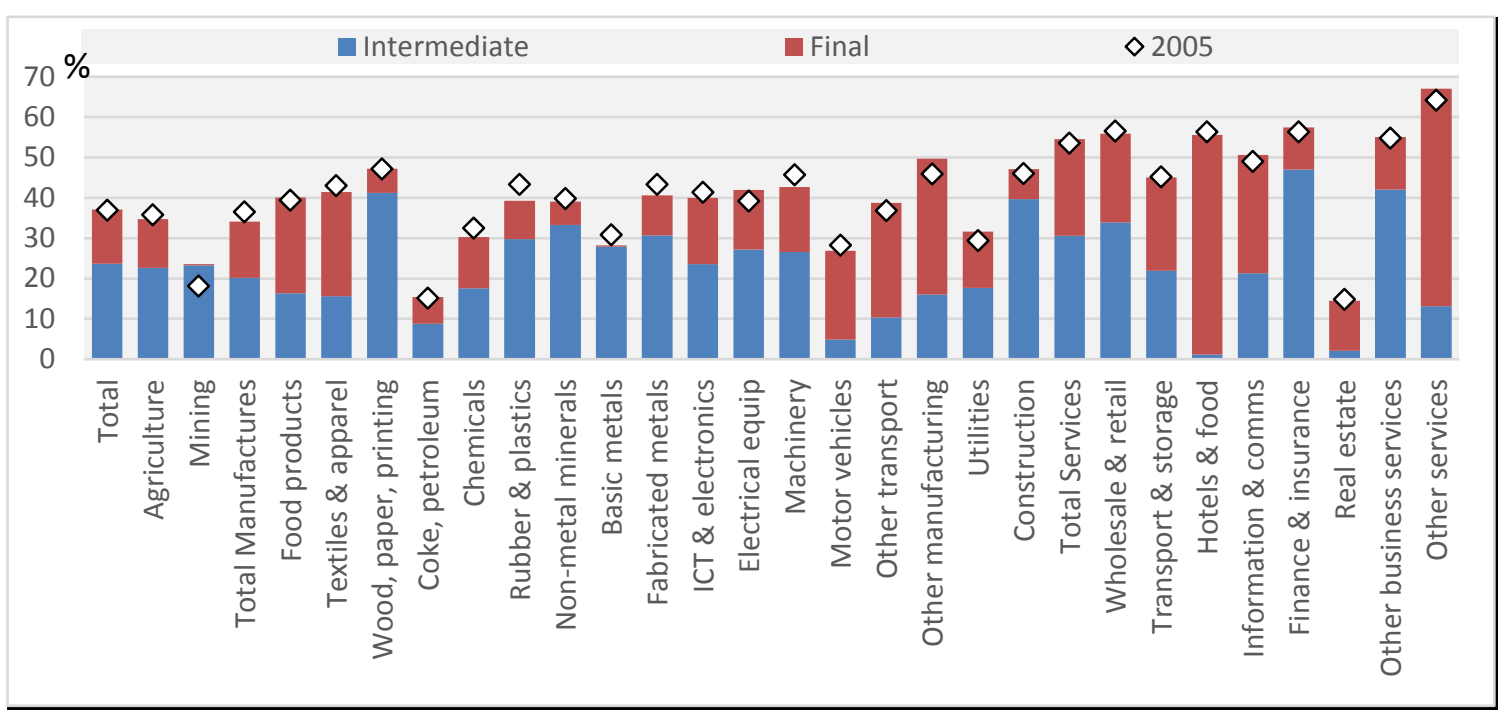

Source: OECD Trade in Employment database, 2019. 


\section{TiM estimates sensitivity to firm heterogeneity}

Empirical evidence from the international trade literature over last 20 years, which emerged mostly due to the availability and exploitation of the new sources of firm or plant-level data, suggests that exporting firms are more productive than non-exporting firms (in terms of labour productivity - often expressed in microdata based papers as the value of shipments over the number of employees; which is the inverse of the employment coefficient used in TiM). The share of exporting firms on total industry population of firms is disproportionally smaller than their share on overall output or employment. Exporters tend to be bigger both in terms of employment and production but also employees in exporting firms earn more, for example see Bernard and Jensen (1999) for the US or Berthou et al. (2015) for selected EU member countries. Export premia in productivity vary by industry and country, for literature review of both empirical results and theoretical models see e.g. Bernard et al. (2012).

The meta-analysis of 30 articles in the field by Martins and Yang (2009) adds evidence towards the positive effect of exporting on productivity. Authors also stress the time dimension where the effect is amplified in the first year when firm starts selling its products abroad and the effect is stronger for firms in developing countries rather than in developed countries.

So naturally, the TiM results are sensitive to the assumption of equal labour productivity of domestic firms and global manufacturers within an industrial sector. The premia in productivity is even higher for exporting firm is also importing, for example see Bernard et al. (2007), but this is outside of the scope of this analysis.

To analyse the robustness of the results presented, tests were undertaken whereby firm heterogeneity was extended synthetically to all countries in the ICIO framework. ICIO industries for all countries, except Mexico and China that are already separated in the ICIO system, were decomposed into global manufacturers and domestic firms in the following manner:

- Global manufactures ("GM") were defined as manufacturing firms whose total production consists solely of manufactured goods (ISIC Rev. 4 industries 10 to 33) that are exported. Global manufactures do not supply their products to any unit in the domestic territory.

- Domestic firms ("DOM") are defined as firms that supply goods and services to the domestic territory but they can export non-manufactured goods and also services.

For this purpose, it was necessary to adjust variables drawn from OECD ICIO tables. The dimension of vector variables increased by the number of different firms $(f=2)$, where first 1 to $k^{*} n$ items correspond to domestic firms and the rest $\left(k^{*} n+1\right.$ to $\left.k^{*} n^{*} f\right)$ to global manufactures (see Table 4.1). 
Table 4.1. Extended variables for heterogeneity simulation

\begin{tabular}{|c|c|c|}
\hline Variable & Dimension & Description \\
\hline$\widetilde{\mathbf{X}}$ & $1 \times\left(k^{*} n^{*} f\right)$ & $\begin{array}{l}\text { Extended gross output vector by country and industry, where } \widetilde{\mathbf{X}}=\mathbf{X} \\
\text { if } \mathrm{f}=\mathrm{DOM} \text { and industry not in manufacturing, } \widetilde{\mathbf{X}}=\mathbf{X}-\mathbf{G T} \text { if } f=\mathrm{DOM} \\
\text { and industry in manufacturing, } \widetilde{\mathbf{X}}=\mathbf{G T} \text { if } f=\mathrm{GM} \text { and industry in } \\
\text { manufacturing, and } \widetilde{\mathbf{X}}=\mathbf{0} \text { if } f=\mathrm{GM} \text { and industry not in } \\
\text { manufacturing }\end{array}$ \\
\hline$\widetilde{\mathbf{e}_{s}^{e}}$ & $\left(k^{*} n^{\star} f\right) \times\left(k^{*} n^{\star} f\right)$ & $\begin{array}{l}\text { Extended diagonalised employment coefficient vector by country, } \\
\text { industry and scenario, where } \widetilde{\mathbf{e}_{s}^{e}}=0 \text { if } \mathrm{f}=\mathrm{GM} \text { and industry not in } \\
\text { manufacturing }\end{array}$ \\
\hline$\tilde{\mathbf{Z}}$ & $\left(k^{*} n^{*} f\right) \times\left(k^{*} n^{*} f\right)$ & Extended Global intermediate consumption matrix \\
\hline$\widetilde{\mathbf{A}}$ & $\left(k^{*} n^{*} f\right) \times\left(k^{*} n^{*} f\right)$ & Extended Global Input-output coefficients matrix, where $\tilde{A}_{i, j}=\frac{\tilde{z}_{i, j}}{\tilde{X}_{j}}$ \\
\hline$\widetilde{\mathbf{B}}$ & $\left(k^{*} n^{*} f\right) \times\left(k^{*} n^{*} f\right)$ & Extended Global Leontief inverse matrix, where $\widetilde{\mathbf{B}}=(\mathbf{I}-\widetilde{\mathbf{A}})^{-\mathbf{1}}$ \\
\hline$\widetilde{\mathrm{GT}}$ & $\left(k^{*} n^{*} f\right) \times k$ & $\begin{array}{l}\text { Extended Global bilateral gross trade matrix, where } \widetilde{\text { GT }}=0 \text { if } \\
\text { ( } f=D O M \text { and industry in manufacturing) or ( } f=G M F \text { and industry not } \\
\text { in manufacturing) }\end{array}$ \\
\hline
\end{tabular}

\subsection{Extended global input-output coefficients matrix}

The most complicated step is to parse the global input-output intermediate transaction matrix for all countries (except Mexico and China) into global manufacturers and domestic firms. In order to keep the structure of the extended global input-output intermediate transaction matrix unchanged compared to the original matrix, additional assumptions were introduced:

- Global manufacturers' production is equal to total manufactured goods exports; and

- the input structure of global manufacturers and domestic firms is identical.

Figure 4.1 illustrates the two-country (A and B) and two-industry (manufacturing- MANU and all other industries- REST) example of parsing the global input-output intermediate transaction matrix into global manufacturers (GM) and domestic firms (DOM). In cases where it was necessary to split transaction into two, e.g. cell $Z_{11}$, the intermediate transaction was multiplied by the share of exports in production to obtain a value for global manufacturers and by its complement for domestic firms' value. Total industry output of manufacturing industries is also distributed in accordance with the first assumption to calculate the extended global Input-output coefficient matrix. The total output of global manufacturers is set to be equal to the total exports and the gross output of domestic manufacturing firms is calculated as the difference between the total gross output and gross exports. 
Figure 4.1. Two-country and two-industry example of Global intermediate consumption matrix split

\begin{tabular}{|c|c|c|c|c|c|}
\hline \multirow{2}{*}{$\begin{array}{l}\text { Country/ } \\
\text { industry }\end{array}$} & \multicolumn{2}{c|}{$\mathrm{A}$} & \multicolumn{2}{c|}{$\mathrm{B}$} \\
\cline { 2 - 6 } & MANU & REST & MANU & REST \\
\hline \multirow{2}{*}{$\mathrm{A}$} & MANU & $\mathrm{Z}_{11}$ & $\mathrm{Z}_{12}$ & $\mathrm{Z}_{13}$ & $\mathrm{Z}_{14}$ \\
\cline { 2 - 6 } & REST & $\mathrm{Z}_{21}$ & $\mathrm{Z}_{22}$ & $\mathrm{Z}_{23}$ & $\mathrm{Z}_{24}$ \\
\hline \multirow{2}{*}{$\mathrm{B}$} & MANU & $\mathrm{Z}_{31}$ & $\mathrm{Z}_{32}$ & $\mathrm{Z}_{33}$ & $\mathrm{Z}_{34}$ \\
\cline { 2 - 6 } & REST & $\mathrm{Z}_{41}$ & $\mathrm{Z}_{42}$ & $\mathrm{Z}_{43}$ & $\mathrm{Z}_{44}$ \\
\hline \multicolumn{2}{|c|}{ OUTPUT } & $\mathrm{X}_{1}$ & $\mathrm{X}_{2}$ & $\mathrm{X}_{3}$ & $\mathrm{X}_{4}$ \\
\hline
\end{tabular}

$$
\mathbf{D}_{\mathrm{j}}=\frac{\mathbf{X}_{\mathrm{j}}-\mathbf{G T}_{\mathrm{j}}}{\mathbf{X}_{\mathrm{j}}} \quad \mathbf{E}_{\mathrm{j}}=\frac{\mathbf{G T}_{\mathrm{j}}}{\mathbf{X}_{\mathrm{j}}}
$$

\begin{tabular}{|c|c|c|c|c|c|c|c|c|c|}
\hline \multirow{3}{*}{\multicolumn{2}{|c|}{$\begin{array}{l}\text { Firm/ } \\
\text { country/ } \\
\text { industry }\end{array}$}} & \multicolumn{4}{|c|}{ DOM } & \multicolumn{4}{|c|}{ GM } \\
\hline & & \multicolumn{2}{|c|}{ A } & \multicolumn{2}{|l|}{ B } & \multicolumn{2}{|c|}{ A } & \multicolumn{2}{|c|}{ B } \\
\hline & & MANU & REST & MANU & REST & MANU & REST & MANU & JREST \\
\hline \multirow{4}{*}{ DOM } & MANU & $\mathrm{Z}_{11} * \mathrm{D}_{1}$ & $Z_{12}$ & 0 & 0 & $\mathrm{Z}_{11} * \mathrm{E}_{1}$ & 0 & 0 & 0 \\
\hline & REST & $\mathrm{Z}_{21} * \mathrm{D}_{1}$ & $Z_{22}$ & $\mathrm{Z}_{23} * \mathrm{D}_{3}$ & $\mathrm{Z}_{24}$ & $\mathrm{Z}_{21} * \mathrm{E}_{1}$ & 0 & $\mathrm{Z}_{23} * \mathrm{E}_{3}$ & 0 \\
\hline & MANU & 0 & 0 & $\mathrm{Z}_{33} * \mathrm{D}_{3}$ & $Z_{34}$ & 0 & 0 & $\mathrm{Z}_{33} * \mathrm{E}_{3}$ & 0 \\
\hline & ${ }^{B}$ REST & $\mathrm{Z}_{41} * \mathrm{D}_{1}$ & $Z_{42}$ & $\mathrm{Z}_{43} * \mathrm{D}_{3}$ & $Z_{44}$ & $\mathrm{Z}_{41} * \mathrm{E}_{1}$ & 0 & $\mathrm{Z}_{43} * \mathrm{E}_{3}$ & 0 \\
\hline \multirow{4}{*}{ GMF } & MANU & 0 & 0 & $\mathrm{Z}_{13} * \mathrm{D}_{3}$ & $Z_{14}$ & 0 & 0 & $\mathrm{Z}_{13} * \mathrm{E}_{3}$ & 0 \\
\hline & REST & 0 & 0 & \begin{tabular}{|l|}
0 \\
\end{tabular} & 0 & 0 & 0 & 0 & 0 \\
\hline & $\mathrm{BANU}$ & $\mathrm{Z}_{31} * \mathrm{D}_{1}$ & $Z_{32}$ & 0 & 0 & $\mathrm{Z}_{31} * \mathrm{E}_{1}$ & 0 & 0 & 0 \\
\hline & REST & \begin{tabular}{|l|} 
\\
\end{tabular} & 0 & 0 & 0 & 0 & 0 & 0 & 0 \\
\hline \multicolumn{2}{|c|}{ OUTPUT } & $\mathrm{X}_{1}-\mathrm{GT}_{1}$ & $\mathrm{X}_{2}$ & $\mathrm{X}_{3}-\mathrm{GT}_{3}$ & $\mathrm{X}_{4}$ & $\mathrm{GT}_{1}$ & 0 & $\mathrm{GT}_{3}$ & 0 \\
\hline
\end{tabular}

\subsection{Sensitivity analysis}

To be able to test the effect of these structural changes to the global input-output coefficient matrix and eliminate the structural change effect for comparison purposes, the baseline scenario with extended variables was estimated. In this scenario, the assumption of equal labour productivity of global manufacturers and domestic firms is preserved to ensure comparability with previous estimates.

Then the set of ten scenarios for employment indicators is estimated with varying firm heterogeneity. In every scenario, the exporter labour productivity premia is set to be either $10 \%, 25 \%, 50 \%, 100 \%$ and 2000 times higher (presented with plus signs "+" in results) or lower (with minus signs "." in results) than of domestic firms. All alternative estimates are calculated similarly to TiM indicator domestic employment embodied in gross exports:

$$
\text { EXGR_DEM }_{s}=\widetilde{\mathbf{e}_{s}^{e}} \times \widetilde{\mathbf{B}} \times \widetilde{\mathbf{G T}}
$$

The transformations of global input-output coefficient matrix has very small effect on the final estimates of jobs embodied in gross exports as can be seen from Figure 4.2. For example in 2015 and all OECD member countries, the relative differences between baseline scenario and EXGR_DEM estimates range from $-0.04 \%$ for Korea to $0.13 \%$ for the United States, which accounts to less than 20 thousand jobs. 
Figure 4.2. OECD countries: Relative difference between baseline scenario of domestic employment embodied in gross exports and original EXGR_DEM estimates, 2015

As share of original total domestic employment embodied in gross exports, percentage

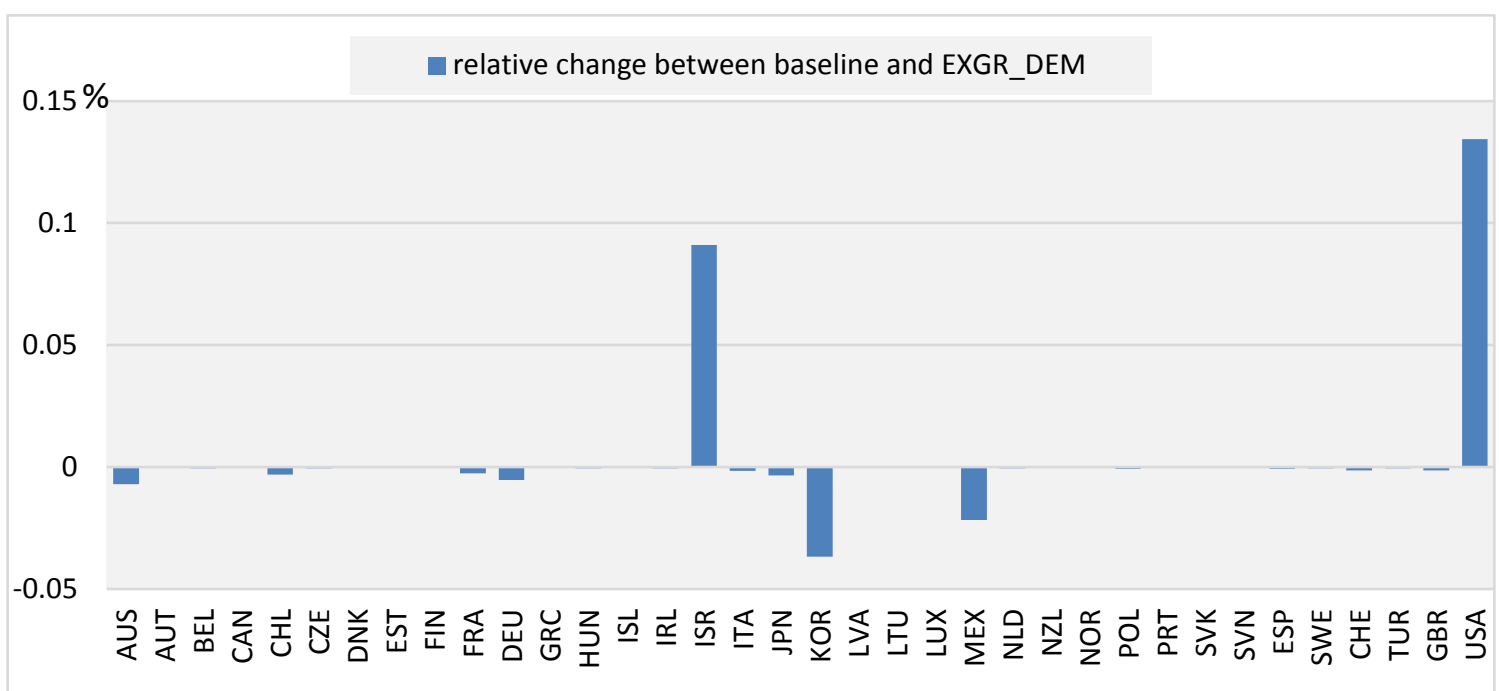

Source: OECD Trade in Employment database and authors' calculations, 2019.

\subsection{Results}

Table 4.2 summarises the mean relative differences and their standard deviations from the baseline scenario of employment embodied in gross exports by industry, for all OECD countries. The results are relatively stable for non-manufacturing industries. Even in the extreme scenarios, the maximum change on average is less than $10 \%$ compared to the baseline. Estimates for the manufacturing industries are significantly more sensitive to changes in underlying assumptions, but even in the case with the assumption of $100 \%$ higher labour productivity of global manufacturers, which is more than the highest value in the literature for developing countries, the average upward bias for total manufacturing industry of TiM estimates due to not accounting for firm heterogeneity is around $10 \%$ and in the extreme scenarios around $30 \%$. 
Table 4.2. OECD countries: Summary of mean relative differences and its standard deviations from baseline scenario, by scenario

\begin{tabular}{|c|c|c|c|c|c|c|c|c|c|c|c|c|c|c|c|}
\hline & $10 \%$ & (SD) & $+10 \%$ & $-25 \%$ & (SD) & $+25 \%$ & $-50 \%$ & (SD) & $+50 \%$ & $-100 \%$ & (SD) & $+100 \%$ & $\min$ & (SD) & nax \\
\hline Total & 58 & .27) & -0.58 & 1.35 & .63) & -1.35 & 2.42 & (1.14) & -2.42 & 4.04 & (1.9) & -4.04 & 2.1 & 5.7) & 12.1 \\
\hline Agric & & $(0.09)$ & 0.18 & -0.42 & $(0.2)$ & 0.42 & $\mid-0.76$ & & 0.76 & -1.27 & & 1.27 & -3.79 & $(1.82)$ & 3.79 \\
\hline Mining & 31 & $(0.14)$ & 0.31 & -0.71 & $(0.32)$ & 0.71 & -1.28 & & 1.28 & & & 2.14 & -6.41 & & 6.41 \\
\hline Total & .47 & $(0.52)$ & -1.47 & 3.42 & $(1.2)$ & -3.42 & 6.16 & $(2.17)$ & -6.16 & 10.27 & (3.61) & -10.27 & 30.77 & .82) & -30.77 \\
\hline Food & 11 & $(0.53)$ & -1.11 & 2.59 & $(1.23)$ & -2.59 & 4.66 & $(2.22)$ & -4.66 & 7.76 & (3.7) & -7.76 & 23.27 & & -23.27 \\
\hline & 53 & $(0.86)$ & -2.53 & 5.91 & (2.01) & -5.91 & 10.64 & & -10.64 & 17.74 & $(6.03)$ & -17.74 & 53. & & -53.16 \\
\hline Wood, & 1.62 & $(0.6)$ & -1.62 & 3.79 & $(1.4)$ & -3.79 & 6.82 & $(2.51)$ & -6.82 & 11.37 & (4.19) & -11.37 & 34.08 & & -34.08 \\
\hline Chen & 1.37 & $(0.56)$ & -1.37 & 3.20 & (1.3) & -3.20 & 5.76 & (2.34) & -5.76 & 9.6 & (3.9) & -9.6 & 28.77 & & -28.77 \\
\hline Meta & 1.6 & $(0.71)$ & -1.6 & 3.74 & $(1.66)$ & -3.74 & 6.74 & (2.9 & -6.74 & 11.23 & $(4.99)$ & -11.23 & 33.65 & & -33.65 \\
\hline ICT, & 1.87 & $(0.74)$ & -1.87 & 4.36 & (1.73) & -4.36 & 7.86 & (3.12) & -7.86 & 13.09 & (5.2) & -13.09 & 39.24 & & -39.24 \\
\hline & & & & & & -4.26 & & & & & & & & & 8.34 \\
\hline Tran & 1.44 & $(0.96)$ & -1.44 & 3.37 & $(2.23)$ & -3.37 & 6.07 & $(4.02)$ & -6.07 & 10.11 & (6.7) & -10.11 & 30.31 & & -30.31 \\
\hline Oth & 2.38 & $(0.64)$ & -2.38 & 5.56 & (1.49) & -5.56 & 10 & (2.68) & -10 & 16.67 & (4.46) & -16.67 & 49.97 & & -49.97 \\
\hline & & $(0.1$ & & -0.69 & $(0.3$ & 0.69 & -1.25 & & & -2.08 & & 2.08 & -6.24 & & 6.24 \\
\hline & -0.45 & $(0.1$ & 0.45 & -1.05 & $(0.36)$ & 1.05 & -1.89 & & 1.89 & -3.14 & & 3.14 & -9.42 & & 9.42 \\
\hline & -0.13 & $(0.05)$ & 0.13 & -0.3 & $(0.12)$ & 0.3 & -0.54 & & 54 & -0.9 & & & -2.69 & & 2.69 \\
\hline & & $(0.05)$ & 0.1 & -0.24 & $(0.1$ & 0.24 & -0.43 & & & -0.72 & & 0.72 & -2.16 & & 2.16 \\
\hline Tran & -0.15 & $(0.06)$ & 0.15 & -0.35 & $(0.15)$ & 0.35 & -0.63 & $(0.26)$ & 0.63 & -1.05 & $(0.44)$ & 1.05 & -3.15 & & 3.15 \\
\hline Acc & -0.19 & $(0.08)$ & 0.19 & -0.44 & $(0.18)$ & 0.44 & -0.8 & & 0.8 & -1.33 & & 1.33 & -4 & & 4 \\
\hline Info & -0.18 & $(0.09)$ & 0.18 & -0.43 & $(0.21)$ & 0.43 & -0.77 & $(0.39)$ & 0.77 & -1.28 & & 1.28 & -3.85 & & 3.85 \\
\hline & -0.09 & $(0.04)$ & 0.09 & -0.22 & $(0.1)$ & 0.22 & -0.39 & & 0.3 & -0.65 & & 0.65 & -1.95 & & 1.95 \\
\hline & -0.1 & $(0.05)$ & 0.1 & -0.24 & (0.11) & 0.24 & -0.43 & $(0.21)$ & 0.43 & -0.72 & $(0.34)$ & 0.72 & -2.16 & (1.03) & 2.16 \\
\hline & -0.08 & $(0.04)$ & 0.08 & $\mid-0.19$ & $(0.09)$ & 0.19 & -0.33 & $(0.17)$ & 0.33 & -0.56 & $(0.28)$ & 0.56 & -1.67 & $(0.83)$ & 1.67 \\
\hline
\end{tabular}

Source: OECD Trade in Employment database and authors' calculations, 2019.

At the total level, as a weighted average for the whole OECD area, the interval between values of extreme scenarios for total employment embodied in gross exports as a share of total employment is less than 4 percentage points, but the case when domestic firms are more productive than exporting firms has significantly smaller occurrence in the literature. The most likely bias in the results for total employment embodied in gross exports as a share of total employment for the OECD area as a weighted average is upward: between $0.08(+10 \%$ scenario) and $0.62(+100 \%$ scenario $)$ percentage points.

Figure 4.3. OECD employment embodied in gross exports (weighted average), by scenario

As share of total employment, percentage

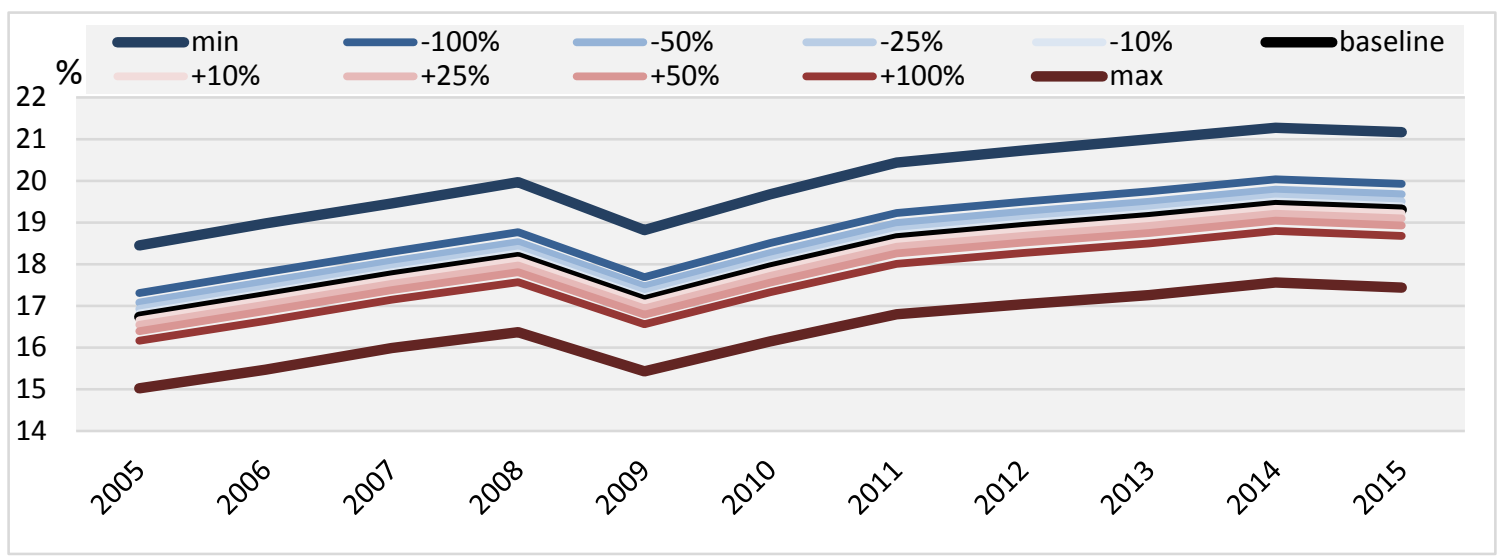

Source: OECD Trade in Employment database and authors' calculations, 2019. 
In the scenario, where global manufacturers are simulated to be twice as productive as domestic firms, the effect on industry employment embodied in gross exports for the OECD area as a weighted average is limited. For example in 2015, the overall $3 \%$ or 0.6 percentage point decrease from $19.3 \%$ to 18.7 in domestic employment embodied in gross exports (around 3.6 million from 112 million jobs) is mainly due to an almost $8 \%$ drop (4.1 million to 49.1 million jobs) in manufacturing employment partially offset by a $0.8 \%$ increase ( 0.4 million to around 50 million jobs) in business service sectors (see Figure 4.4).

Figure 4.4. Relative difference between $-100 \%$ and baseline scenario for the OECD area, weighted average, by industry, 2015

As share of baseline's industry employment, percentage

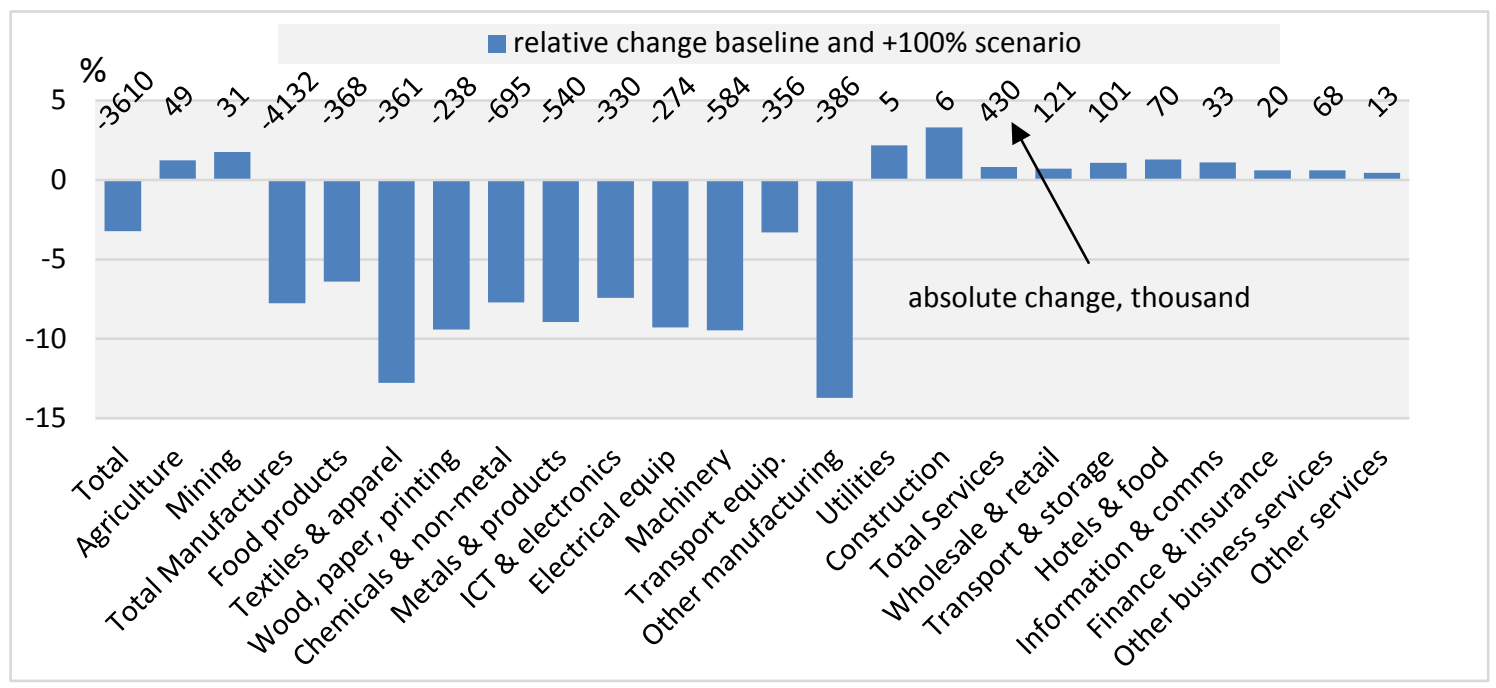

Source: OECD Trade in Employment database and authors' calculations, 2019.

As expected, the manufacturing industry is the main industry affected by the productivity heterogeneity simulations but this varies by country. The results shown in Figure 4.5 can be presented as a confidence interval for the manufacturing industry employment embodied in gross exports. For example, in Germany, when accounting for firm heterogeneity, the manufacturing employment embodied in gross exports can be between 6.4 and 7 million persons compared to 7.1 million in baseline scenario. 
Figure 4.5. Confidence interval for manufacturing employment embodied in gross exports based on $+10 \%$ and $+100 \%$ scenarios, by country in 2015

As relative change to baseline scenario, percentage

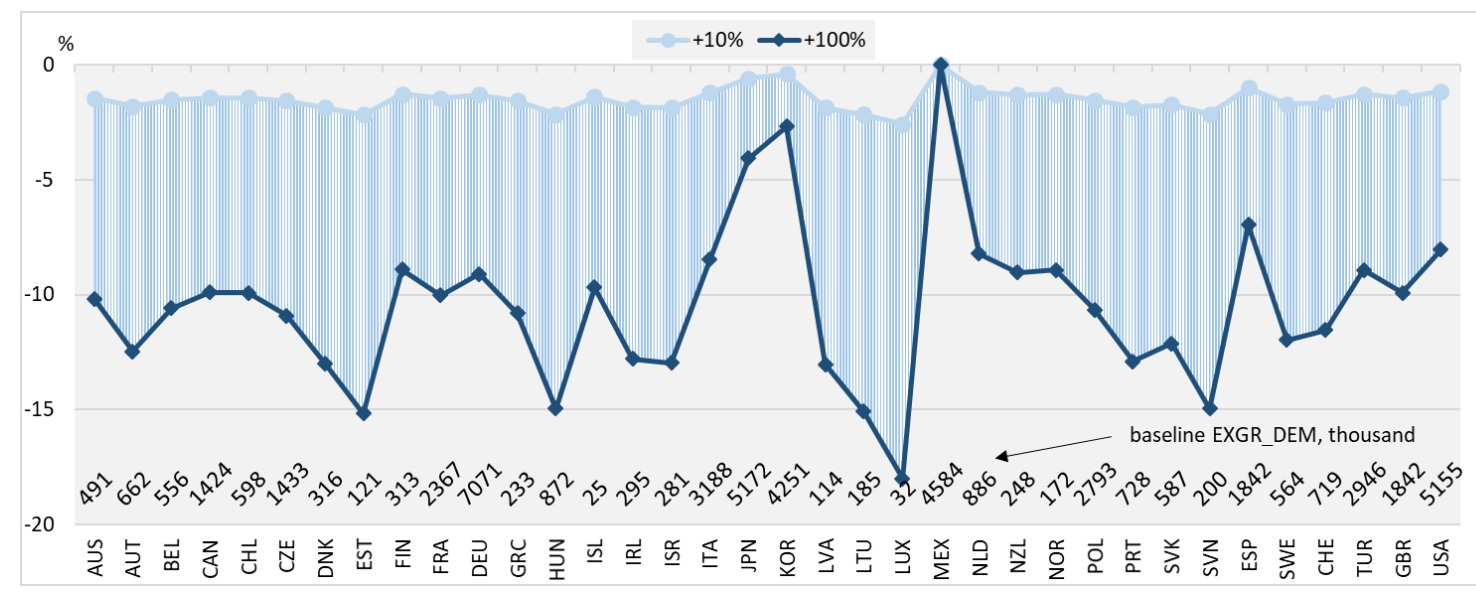

Source: OECD Trade in Employment database and authors' calculations, 2019. 


\section{Notes}

${ }^{1}$ For more information about global manufacturers and domestic firms, see Chapter 4.

${ }^{2}$ Total employment may include unpaid family members living on a farm without any corresponding market output.

${ }^{3}$ Biproportional matrix balancing method developed by Junius and Oosterhaven (2003)

${ }^{4}$ Calculated as $E M C E=\frac{E M P N}{L A B R}$

${ }^{5}$ For hierarchical structure of industries see Appendix B

${ }^{6}$ Depending on the sector chosen. Typically, there is more self-employed persons in services than in manufacturing sectors. 


\section{References}

Alsamawi, A., J. Murray, and M. Lenzen (2014) “The Employment Footprints of Nations: Uncovering Master Servant Relationships," Journal of Industrial Ecology, Vol. 18, pp. 59-70, http://dx.doi.org/10.1111/jiec.12104.

Benz, S. and L. Johannesson (2019) "Job characteristics, job transitions and services trade: Evidence from the EU labour force survey," OECD Trade Policy Papers, No. 225, http://dx.doi.org/10.1787/bb21f81a-en.

Bernard, A. B. and J. B. Jensen (1995) "Exporters, Jobs, and Wages in U.S. Manufacturing:1976-1987," Brookings Papers on Economic Activity. Microeconomics, No. 1995, pp. 67-119.

Bernard, A. B. and J. B. Jensen (1999) "Exceptional exporter performance: cause, effect, or both?" Journal of International Economics, Vol. 47, pp. 1-25.

Bernard, A. B., J. B. Jensen, S. J. Redding, and P. K. Scott (2007) "Firms in international trade," Journal of Economic Perspectives, Vol. 21, No. 3, pp. 105-130, http://dx.doi.org/10.1257/jep.21.3.105.

Bernard, A. B., J. B. Jensen, S. J. Redding, and P. K. Scott (2012) "The empirics of firm heterogeneity and international trade," Annual Review of Economics, Vol. 4, pp. 283-313, http://dx.doi.org/10.1146/annurev-economics-080511-110928.

Berthou, A., E. Dhyne, M. Bugamelli, A. Cazacu, C. Demian, P. Harasztosi, T. Lalinsky, J. Merikül, F. Oropallo, and A. C. Soares (2015) "Assessing European firms' exports and productivity distributions: the CompNet trade module," Working Paper Series- European Central Bank, Vol. 1788.

Das, D. K., A. A. Erumban, S. Aggarwal, and P. C. Das (2017) "Measuring Productivity at the Industry Level, THE INDIA KLEMS DATA BASE DATA MANUAL 2017 (Version 4)."

De Backer, K. and N. Yamano (2007) "The Measurement of Globalisation using International Input-Output Tables," OECD Science, Technology and Industry Working Papers, No.2007/08, http://dx.doi.org/10.1787/242020221356.

Dietzenbacher, E., B. Los, R. Stehrer, M. Timmer, and G. de Vries (2013) "The Construction of World Input-Output Tables in The WIOD Project," Economic Systems Research, Vol. 25, No. 1, pp. 71-98, http://dx.doi.org/10.1080/09535314.2012.761180.

Jäger, K. (2018) "EU KLEMS Growth and Productivity Accounts 2017 release Description of Methodology and General Notes," The Conference Board, Vol. July, http://euklems.net/index.html.

Junius, T. and J. Oosterhaven (2003) "The Solution of Updating or Regionalizing a Matrix with both Positive and Negative Entries," Economic System Research, Vol. 15, No. 1, pp. 87-96, https://doi.org/10.1080/0953531032000056954.

Lenzen, M., D. Moran, and K. Kanemoto (2013) "Building Eora: A Global Multiregional Input-Output Database at High Country and Sector Resolution," 
Economic Systems Research, Vol. 25, No. 1, pp. 20-49, https://doi.org/10.1080/09535314.2013.769938.

Los, B., M. Timmer, and G. de Vries (2015) "How important are exports for job growth in China? A demand side analysis," Journal of Comparative Economics, Vol. 43, No. 1, pp.19-32, http://dx.doi.org/10.1016/j.jce.2014.11.007.

Marcolin, L., S. Miroudot, and M. Squicciarini (2016) "GVCs, Jobs And Routine Content Of Occupations," OECD Trade Policy Papers, No. 187, http://dx.doi.org/10.1787/5jm0mq7kr6s8-en.

Martins, P. and Y. Yang (2009) "The impact of exporting on firm productivity: a metaanalysis of the learning-by-exporting hypothesis," Review of World Economics, Vol. 145, No. 3, pp. 431-445, http://dx.doi.org/10.1007/s10290-009-0021-6.

Miller, R. and P. Blair (2009) Input-Output Analysis: Foundations and Extensions, Cambridge: Cambridge University Press.

OECD (2015), OECD Science, Technology and Industry Scoreboard 2015: Innovation for growth and society, OECD Publishing, Paris, https://doi.org/10.1787/sti_scoreboard-2015-en.

OECD (2016) "Global Value Chains and Trade in Value-Added: An Initial Assessment of the Impact on Jobs and Productivity," OECD Trade Policy Papers, No. 190, http://dx.doi.org/doi.org/10.1787/18166873.

OECD (2017), OECD Science, Technology and Industry Scoreboard 2017: The digital transformation, OECD Publishing, Paris, https://doi.org/10.1787/9789264268821-en.

OECD (2018a) Input-Output Database: http://oe.cd/i-o.

OECD (2018b) Inter-Country Input-Output (ICIO) Database: http://oe.cd/icio.

OECD (2018c) STructural ANalysis (STAN) Database: http://oe.cd/stan.

OECD (2018d) Trade in Value Added (TiVA) Database: http://oe.cd/tiva.

OECD (2019) Guide to OECD's Trade in Value Added (TiVA) Indicators, 2018 edition: www.oecd.org/sti/ind/tiva/TiVA2018 Indicators Guide.pdf

Portella-Carbó, F. (2018) "Effects of International Trade on Domestic Employment: an Application of a Global Multiregional Input-Output Supermultiplier model (19952011)," Economic Systems Research, Vol. 28, No. 1, pp. 95-117, http://dx.doi.org/10.1080/09535314.2016.1142429. 


\section{Appendix A-TiM Country list}

\begin{tabular}{|c|c|c|c|c|c|c|c|c|c|c|c|c|c|c|c|c|}
\hline \multicolumn{2}{|c|}{ Countries $\backslash$ Region aggregates } & OECD & APEC & ASEAN & EASIA & EU28 & EU15 & EU13 & EA19 & EA12 & $\mathrm{G} 20$ & ZEUR & ZASI & ZNAM & ZOTH & ZSCA \\
\hline $1 \mathrm{AUS}$ & Australia & $\mathrm{x}$ & $x$ & & & & & & & & $x$ & & & & $x$ & \\
\hline 2 AUT & Austria & $\mathrm{x}$ & & & & $x$ & $\mathrm{x}$ & & $x$ & $x$ & & $\mathrm{x}$ & & & & \\
\hline 3 BEL & Belgium & $x$ & & & & $x$ & $x$ & & $x$ & $x$ & & $\mathrm{x}$ & & & & \\
\hline 4 CAN & Canada & $x$ & $\mathrm{x}$ & & & & & & & & $x$ & & & $\mathrm{x}$ & & \\
\hline $5 \mathrm{CHL}$ & Chile & $x$ & $x$ & & & & & & & & & & & & & $x$ \\
\hline 6 CZE & Czech Republic & $x$ & & & & $x$ & & $x$ & & & & $x$ & & & & \\
\hline 7 DNK & Denmark & $x$ & & & & $x$ & $x$ & & & & & $x$ & & & & \\
\hline 8 EST & Estonia & $x$ & & & & $x$ & & $\mathrm{x}$ & $\mathrm{x}$ & & & $x$ & & & & \\
\hline 9 FIN & Finland & $x$ & & & & $x$ & $\mathrm{x}$ & & $x$ & $x$ & & $x$ & & & & \\
\hline 10 FRA & France & $x$ & & & & $x$ & $x$ & & $x$ & $x$ & $x$ & $x$ & & & & \\
\hline $11 \mathrm{DEU}$ & Germany & $x$ & & & & $x$ & $x$ & & $x$ & $x$ & $x$ & $x$ & & & & \\
\hline 12 GRC & Greece & $x$ & & & & $x$ & $x$ & & $x$ & $x$ & & $x$ & & & & \\
\hline $13 \mathrm{HUN}$ & Hungary & $x$ & & & & $x$ & & $x$ & & & & $x$ & & & & \\
\hline 14 ISL & Iceland & $x$ & & & & & & & & & & $x$ & & & & \\
\hline $15 \mathrm{IRL}$ & Ireland & $x$ & & & & $\mathrm{x}$ & $\mathrm{x}$ & & $x$ & $\mathrm{x}$ & & $x$ & & & & \\
\hline 16 ISR & Israel & $x$ & & & & & & & & & & & & & $x$ & \\
\hline 17 ITA & Italy & $x$ & & & & $x$ & $\mathrm{x}$ & & $x$ & $\mathrm{x}$ & $\mathrm{x}$ & $x$ & & & & \\
\hline 18 JPN & Japan & $x$ & $x$ & & $x$ & & & & & & $x$ & & $x$ & & & \\
\hline $19 \mathrm{KOR}$ & Korea & $x$ & $x$ & & $\mathrm{x}$ & & & & & & $x$ & & $x$ & & & \\
\hline 20 LVA & Latvia & $x$ & & & & $x$ & & $x$ & $\mathrm{x}$ & & & $x$ & & & & \\
\hline $21 \mathrm{LTU}$ & Lithuania & $x$ & & & & $x$ & & $x$ & $x$ & & & $x$ & & & & \\
\hline 22 LUX & Luxembourg & $x$ & & & & $x$ & $\mathrm{x}$ & & $x$ & $x$ & & $x$ & & & & \\
\hline 23 MEX & Mexico & $x$ & $x$ & & & & & & & & $x$ & & & $x$ & & \\
\hline 24 NLD & Netherlands & $x$ & & & & $\mathrm{x}$ & $x$ & & $x$ & $x$ & & $x$ & & & & \\
\hline 25 NZL & New Zealand & $x$ & $x$ & & & & & & & & & & & & $x$ & \\
\hline 26 NOR & Norway & $x$ & & & & & & & & & & $x$ & & & & \\
\hline 27 POL & Poland & $x$ & & & & $\mathrm{x}$ & & $x$ & & & & $x$ & & & & \\
\hline 28 PRT & Portugal & $x$ & & & & $x$ & $x$ & & $\mathrm{x}$ & $x$ & & $x$ & & & & \\
\hline 29 SVK & Slovak Republic & $x$ & & & & $x$ & & $x$ & $x$ & & & $x$ & & & & \\
\hline $30 \mathrm{SVN}$ & Slovenia & $x$ & & & & $x$ & & $x$ & $x$ & & & $x$ & & & & \\
\hline $31 \mathrm{ESP}$ & Spain & $x$ & & & & $x$ & $x$ & & $x$ & $x$ & & $x$ & & & & \\
\hline 32 SWE & Sweden & $x$ & & & & $x$ & $x$ & & & & & $x$ & & & & \\
\hline $33 \mathrm{CHE}$ & Switzerland & $x$ & & & & & & & & & & $x$ & & & & \\
\hline 34 TUR & Turkey & $x$ & & & & & & & & & $\mathrm{x}$ & & & & $\mathrm{x}$ & \\
\hline 35 GBR & United Kingdom & $x$ & & & & $x$ & $\mathrm{x}$ & & & & $\mathrm{x}$ & $\mathrm{x}$ & & & & \\
\hline 36 USA & United States & $\mathrm{x}$ & $\mathrm{x}$ & & & & & & & & $\mathrm{x}$ & & & $\mathrm{x}$ & & \\
\hline 37 ARG & Argentina & & & & & & & & & & $x$ & & & & & $x$ \\
\hline 38 BRA & Brazil & & & & & & & & & & $x$ & & & & & $x$ \\
\hline 39 BRN & Brunei Darussalam & & $x$ & $\mathrm{x}$ & & & & & & & & & $x$ & & & \\
\hline 40 BGR & Bulgaria & & & & & $x$ & & $x$ & & & & $x$ & & & & \\
\hline $41 \mathrm{KHM}$ & Cambodia & & & $x$ & & & & & & & & & $x$ & & & \\
\hline $42 \mathrm{CHN}$ & China & & $\mathrm{x}$ & & $x$ & & & & & & $\mathrm{x}$ & & $x$ & & & \\
\hline $43 \mathrm{COL}$ & Colombia & & & & & & & & & & & & & & & $x$ \\
\hline $44 \mathrm{CRI}$ & Costa Rica & & & & & & & & & & & & & & & $x$ \\
\hline $45 \mathrm{HRV}$ & Croatia & & & & & $x$ & & $x$ & & & & $\mathrm{x}$ & & & & \\
\hline $46 \mathrm{CYP}$ & Cyprus & & & & & $x$ & & $x$ & $x$ & & & $x$ & & & & \\
\hline 47 HKG & Hong Kong, China & & $x$ & & $\mathrm{x}$ & & & & & & & & $x$ & & & \\
\hline 48 IND & India & & & & & & & & & & $x$ & & & & $x$ & \\
\hline 49 IDN & Indonesia & & $x$ & $x$ & & & & & & & $x$ & & $x$ & & & \\
\hline $50 \mathrm{KAZ}$ & Kazakhstan & & & & & & & & & & & & & & $x$ & \\
\hline 51 MYS & Malaysia & & $x$ & $x$ & & & & & & & & & $x$ & & & \\
\hline 52 MLT & Malta & & & & & $x$ & & $x$ & $x$ & & & $x$ & & & & \\
\hline 53 MAR & Morocco & & & & & & & & & & & & & & $\mathrm{x}$ & \\
\hline 54 PER & Peru & & $\mathrm{x}$ & & & & & & & & & & & & $x$ & $x$ \\
\hline 55 PHL & Philippines & & $x$ & $x$ & & & & & & & & & $x$ & & & \\
\hline $56 \mathrm{ROU}$ & Romania & & & & & $\mathrm{x}$ & & $x$ & & & & $x$ & & & & \\
\hline 57 RUS & Russian Federation & & $x$ & & & & & & & & $x$ & $x$ & & & & \\
\hline 58 SAU & Saudi Arabia & & & & & & & & & & $x$ & & & & $x$ & \\
\hline 59 SGP & Singapore & & $x$ & $x$ & & & & & & & & & $x$ & & & \\
\hline $60 \mathrm{ZAF}$ & South Africa & & & & & & & & & & $x$ & & & & $x$ & \\
\hline 61 TWN & Chinese Taipei & & $x$ & & $x$ & & & & & & & & $x$ & & & \\
\hline 62 THA & Thailand & & $x$ & $x$ & & & & & & & & & $x$ & & & \\
\hline 63 TUN & Tunisia & & & & & & & & & & & & & & $x$ & \\
\hline 64 VNM & Viet Nam & & $x$ & $x$ & & & & & & & & & $x$ & & & \\
\hline 65 ROW & Rest of the World & & & & & & & & & & & & & & $x$ & \\
\hline
\end{tabular}


Note by Turkey: The information in this document with reference to 'Cyprus' relates to the southern part of the Island. There is no single authority representing both Turkish and Greek Cypriot people on the Island. Turkey recognises the Turkish Republic of Northern Cyprus (TRNC). Until a lasting and equitable solution is found within the context of the United Nations, Turkey shall preserve its position concerning the 'Cyprus issue'.

Note by all the European Union Member States of the OECD and the European Union:

The Republic of Cyprus is recognised by all members of the United Nations with the exception of Turkey. The information in this document relates to the area under the effective control of the Government of the Republic of Cyprus. 


\section{Appendix B- TiM industry list}

\begin{tabular}{|c|c|}
\hline ind & Label \\
\hline DTOTAL & Total industry \\
\hline D01T03 & Agriculture, forestry and fishing \\
\hline D05T39 & Industry (mining, manufactures and utilities) \\
\hline D05T09 & Mining and quarrying \\
\hline D05T06 & Mining and extraction of energy producing products \\
\hline D07T08 & Mining and quarrying of non-energy producing products \\
\hline D09 & Mining support service activities \\
\hline D10T33 & Manufacturing \\
\hline D10T12 & Food products, beverages and tobacco \\
\hline D13T15 & Textiles, wearing apparel, leather and related products \\
\hline D16T18 & Wood and paper products; printing \\
\hline D16 & Wood and products of wood and cork \\
\hline D17T18 & Paper products and printing \\
\hline D19T23 & Chemicals and non-metallic mineral products \\
\hline D19 & Coke and refined petroleum products \\
\hline D20T21 & Chemicals and pharmaceutical products \\
\hline D22 & Rubber and plastic products \\
\hline D23 & Other non-metallic mineral products \\
\hline D24T25 & Basic metals and fabricated metal products \\
\hline D24 & Basic metals \\
\hline D25 & Fabricated metal products \\
\hline D26T27 & Computers, electronic and electrical equipment \\
\hline D26 & Computer, electronic and optical products \\
\hline D27 & Electrical equipment \\
\hline D28 & Machinery and equipment, nec \\
\hline D29T30 & Transport equipment \\
\hline D29 & Motor vehicles, trailers and semi-trailers \\
\hline D30 & Other transport equipment \\
\hline D31T33 & Other manufacturing; repair and installation of machinery and equipment \\
\hline D35T39 & Electricity, gas, water supply, sewerage, waste and remediation services \\
\hline D41T43 & Construction \\
\hline D45T98 & Total services \\
\hline D45T82 & Total business sector services \\
\hline D45T56 & Distributive trade, transport, accommodation and food services \\
\hline D45T47 & Wholesale and retail trade; repair of motor vehicles \\
\hline D49T53 & Transportation and storage \\
\hline D55T56 & Accommodation and food services \\
\hline D58T63 & Information and communication \\
\hline D58T60 & Publishing, audiovisual and broadcasting activities \\
\hline D61 & Telecommunications \\
\hline D62T63 & IT and other information services \\
\hline D64T66 & Financial and insurance activities \\
\hline D68 & Real estate activities \\
\hline D69T82 & Other business sector services \\
\hline D84T98 & Public admin., education and health; social and personal services \\
\hline D84T88 & Public admin., defence; education and health \\
\hline D84 & Public admin. and defence; compulsory social security \\
\hline D85 & Education \\
\hline D86T88 & Human health and social work \\
\hline D90T98 & Other social and personal services \\
\hline D90T96 & Arts, entertainment, recreation and other service activities \\
\hline D97T98 & Private households with employed persons \\
\hline D58T82 & Information, finance, real estate and other business services \\
\hline D41T98 & Total services (incl. construction) \\
\hline DINFO & Information industries \\
\hline
\end{tabular}




\section{Appendix C- Country notes}

For detailed country and industry notes please visit: $<$ Link forthcoming $>$

The table below comprises a summary of primary sources of Employment and Compensation of employees by industry for each country, if any further estimation outside of STAN framework (chapter 2.2) were necessary and measures of employment, where:

- ANA is annual or annualized national accounts data from international or national sources,

- LFS- annualised Labour Force survey,

- EST- country-specific sources, for more detail see detail country notes available here: $<$ Link forthcoming $>$,

- IOT- Benchmark National Accounts Official Country Data: United Nations Statistics Division (UNSD) for Total industry Compensation of employees distributed by Input-output or Use table industry structure,

- P- partial estimations, usually for industry detail of Mining and quarrying (D05T09) for a few years and

- M- major estimations, when data are missing for all years or multiple industries. 


\begin{tabular}{|c|c|c|c|c|c|c|c|c|c|}
\hline \multirow[b]{2}{*}{ Country } & \multicolumn{2}{|c|}{ Primary source } & \multirow{2}{*}{$\begin{array}{c}\text { Estimations } \\
\text { outside STAN }\end{array}$} & \multirow{2}{*}{$\begin{array}{c}\text { Employment } \\
\text { measure }\end{array}$} & \multirow[b]{2}{*}{ Country } & \multicolumn{2}{|c|}{ Primary source } & \multirow{2}{*}{$\begin{array}{l}\text { Estimations } \\
\text { outside STAN }\end{array}$} & \multirow{2}{*}{$\begin{array}{c}\text { Employment } \\
\text { measure }\end{array}$} \\
\hline & Employment & $\begin{array}{l}\text { Compensation } \\
\text { of employees }\end{array}$ & & & & Employment & $\begin{array}{l}\text { Compensation } \\
\text { of employees }\end{array}$ & & \\
\hline Australia & LFS & ANA & $\mathrm{P}$ & persons & Argentina & ANA & ANA & $P$ & jobs \\
\hline Austria & ANA & ANA & $P$ & persons & Brazil & ANA & ANA & $P$ & jobs \\
\hline Belgium & ANA & ANA & $\mathrm{P}$ & persons & Brunei Darussalam & & IOT & M & \\
\hline Canada & ANA & ANA & & jobs & Bulgaria & ANA & ANA & $P$ & persons \\
\hline Chile & LFS & ANA & M & persons & Cambodia & & IOT & M & \\
\hline Czech Republic & ANA & ANA & & persons & China & EST & IOT & $M$ & persons \\
\hline Denmark & ANA & ANA & $\mathrm{P}$ & persons & Colombia & ANA & IOT & M & persons \\
\hline Estonia & ANA & ANA & $P$ & persons & Costa Rica & ANA & ANA & $M$ & persons \\
\hline Finland & ANA & ANA & & persons & Croatia & ANA & ANA & $M$ & persons \\
\hline France & ANA & ANA & $\mathrm{P}$ & persons & Cyprus & ANA & ANA & $P$ & persons \\
\hline Germany & ANA & ANA & $\mathrm{P}$ & persons & Hong Kong, China & & $\mathrm{IOT}$ & M & \\
\hline Greece & ANA & ANA & $\mathrm{P}$ & persons & India & EST & ANA & M & persons \\
\hline Hungary & ANA & ANA & $\mathrm{P}$ & persons & Indonesia & LFS & IOT & M & persons \\
\hline Iceland & LFS & ANA & $M$ & persons & Kazakhstan & & IOT & $M$ & \\
\hline Ireland & ANA & ANA & $\mathrm{P}$ & persons & Malaysia & & IOT & $M$ & \\
\hline Israel & ANA & ANA & $M$ & jobs & Malta & ANA & ANA & M & persons \\
\hline Italy & ANA & ANA & $\mathrm{P}$ & persons & Morocco & & IOT & M & \\
\hline Japan & ANA & ANA & $\mathrm{P}$ & persons & Peru & & IOT & M & \\
\hline Korea & LFS & ANA & $\mathrm{P}$ & persons & Philippines & & IOT & M & \\
\hline Latvia & ANA & ANA & $\mathrm{P}$ & persons & Romania & ANA & ANA & & persons \\
\hline Lithuania & ANA & ANA & $\mathrm{P}$ & persons & Russian Federation & LFS & ANA & & persons \\
\hline Luxembourg & ANA & ANA & $M$ & persons & Saudi Arabia & LFS & ANA & M & persons \\
\hline Mexico & ANA & ANA & & jobs & Singapore & & IOT & $M$ & \\
\hline Netherlands & ANA & ANA & $\mathrm{P}$ & persons & South Africa & LFS & ANA & M & persons \\
\hline New Zealand & ANA & ANA & $\mathrm{P}$ & persons & Chinese Taipei & & IOT & M & \\
\hline Norway & ANA & ANA & $P$ & persons & Thailand & & IOT & $M$ & \\
\hline Poland & ANA & ANA & $\mathrm{P}$ & persons & Tunisia & & IOT & $M$ & \\
\hline Portugal & ANA & ANA & $\mathrm{P}$ & persons & Viet nam & & IOT & $M$ & \\
\hline Slovak Republic & ANA & ANA & & persons & & & & & \\
\hline Slovenia & ANA & ANA & $\mathrm{P}$ & persons & & & & & \\
\hline Spain & ANA & ANA & & persons & & & & & \\
\hline Sweden & ANA & ANA & & persons & & & & & \\
\hline Switzerland & ANA & EST & M & persons & & & & & \\
\hline Turkey & LFS & ANA & M & persons & & & & & \\
\hline United Kingdom & ANA & ANA & & persons & & & & & \\
\hline United States & ANA & ANA & & jobs & & & & & \\
\hline
\end{tabular}

Note by Turkey: The information in this document with reference to 'Cyprus' relates to the southern part of the Island. There is no single authority representing both Turkish and Greek Cypriot people on the Island. Turkey recognises the Turkish Republic of Northern Cyprus (TRNC). Until a lasting and equitable solution is found within the context of the United Nations, Turkey shall preserve its position concerning the 'Cyprus issue'.

Note by all the European Union Member States of the OECD and the European Union:

The Republic of Cyprus is recognised by all members of the United Nations with the exception of Turkey. The information in this document relates to the area under the effective control of the Government of the Republic of Cyprus. 